\title{
12. TURBIDITE SEDIMENTATION IN THE NANKAI TROUGH AS INTERPRETED FROM MAGNETIC FABRIC, GRAIN SIZE, AND DETRITAL MODAL ANALYSES ${ }^{1}$
}

\author{
Asahiko Taira, Department of Geology, Kochi University \\ and \\ Nobuaki Niitsuma, Institute of Geosciences, Shizuoka University ${ }^{2}$
}

\begin{abstract}
At Site 582, DSDP Leg 87, turbidites $\sim 560 \mathrm{~m}$ thick were recovered from the floor of the Nankai Trough. A turbidite bed is typically composed of three subdivisions: a lower graded sand unit, an upper massive silt unit, and an uppermost Chondrites burrowed silt unit. The turbidites intercalate with bluish gray hemipelagic mud which apparently accumulated below the calcite compensation depth. In order to investigate the nature and provenance of the turbidites, we studied the grain orientation, based on magnetic fabric measurements and thin-section grain counting, and grain size, using a photo-extinction settling tube and detrital modal analysis.

The following results were obtained: (1) grain orientation analysis indicates that the turbidity current transport parallels the trench axis, predominantly from the northeast; (2) Nankai Trough turbidites generally decrease in grain size to the southwest; (3) turbidite sands include skeletal remains indicative of fresh-water and shallow-marine environments; and (4) turbidites contain abundant volcanic components, and their composition is analogous to the sediments of the Fuji River-Suruga Bay area. Considering other evidence, such as physiography and geometry of trench fill, we conclude that the turbidites of Site $\mathbf{5 8 2}$ as well as Site 583 were derived predominantly from the mouth of Fuji River and were transported through the Suruga Trough to the Nankai Trough, a distance of some $700 \mathrm{~km}$. This turbidite transport system has tectonic implications: (1) the filling of the Nankai Trough is the direct consequence of the Izu collision in Pliocene-Pleistocene times; (2) the accretion of trench fill at the trench inner slope observed in the Nankai Trough is controlled by collision tectonics; and (3) each event of turbidite deposition may be related to a Tokai mega-earthquake.
\end{abstract}

\section{INTRODUCTION}

The Nankai Trough is a unique trench for several reasons (Sugimura, 1978): (1) it is shallow with a maximum depth less than $5000 \mathrm{~m}$; (2) the Wadati-Benioff Zone is vague and short in length; (3) heat flow is high; and (4) the volcanic arc is poorly developed in southwestern Japan. The last three of these characteristics may be related to the geologic youth of the subducting plate, which consists of the Oligocene-Miocene Shikoku Basin (Kagami, et al., 1983). The shallowness of the trench is directly related to the thick sequence of sediments it contains, reaching a maximum thickness of $3000 \mathrm{~m}$. The active accretion of sediments at the Nankai Trough, as delineated from seismic reflection profiles (site chapter, Site 583 , this volume), is probably controlled by this thick sedimentary body, providing a valuable opportunity to study both the mechanism and the depositional facies of trench sedimentation.

During Leg 31, Site 298 was drilled into the toe of the Nankai accretionary prism. Unfortunately, core recovery was too poor to study the nature of trench sedimentation and no conclusive evidence was obtained regarding the transport and provenance of turbidite sands.

\footnotetext{
${ }^{1}$ Kagami, H., Karig, D. E., Coulbourn, W. T., et al., Init. Repts. DSDP, 87: Washington (U.S. Govt. Printing Office).

2 Addresses: (Taira, present address) Ocean Research Institute, University of Tokyo, Tokyo 164, Japan; (Niitsuma) Institute of Geosciences, Shizuoka University, Shizuoka 422, Japan.
}

During Leg 87, 11 holes were drilled off Shikoku both in the undeformed and in the deformed trench sediments (Fig. 1). The recovered sediments consist of two units: an upper turbidite unit (Unit 1) and a lower hemipelagite unit (Unit 2). Unit 1 , which is $500 \mathrm{~m}$ thick, is composed of interbedded sandstone and shale with turbidite sedimentary structures. The purpose of this study is to investigate the paleocurrent, detrital mode, and grainsize distribution of turbidite deposits in both Units 1 and 2 in order to clarify the provenance, depositional facies, and mechanism of turbidite sedimentation in this trench environment.

\section{ANALYTICAL TECHNIQUES}

\section{Sampling}

On board the Glomar Challenger, the working halves of cores were sampled using $2.2-\mathrm{cm}^{3}$ plastic cases for magnetic analyses. Undisturbed parts of the core were sampled, but some disturbed parts were also sampled for comparison. Routine $5-10-\mathrm{cm}^{3}$ samples were also obtained for petrologic and grain-size analyses. In this study, about 500 other samples from the area adjacent to the Nankai Trough were also examined for grain size and provenance (see Fig. 1).

\section{Magnetic Fabric Analysis}

The magnetic susceptibility of most sediment is anisotropic because of the preferred orientation of ferromagnetic minerals. Anisotropy of susceptibility in magnetite and titanomagnetite is related to grain shape; the maximum susceptibility is aligned in the direction of the longest axis, and the minimum susceptibility is oriented along the shortest axis. Therefore, sedimentary rocks usually contain a resultant susceptibility anisotropy that may be approximated by a second-order tensor; its main axes represented by $K \max$ (maximum susceptibility), $K$ int (intermediate susceptibility), and $K \min$ (minimum susceptibility) (Rees, 1965; Taira and Lienert, 1979). 


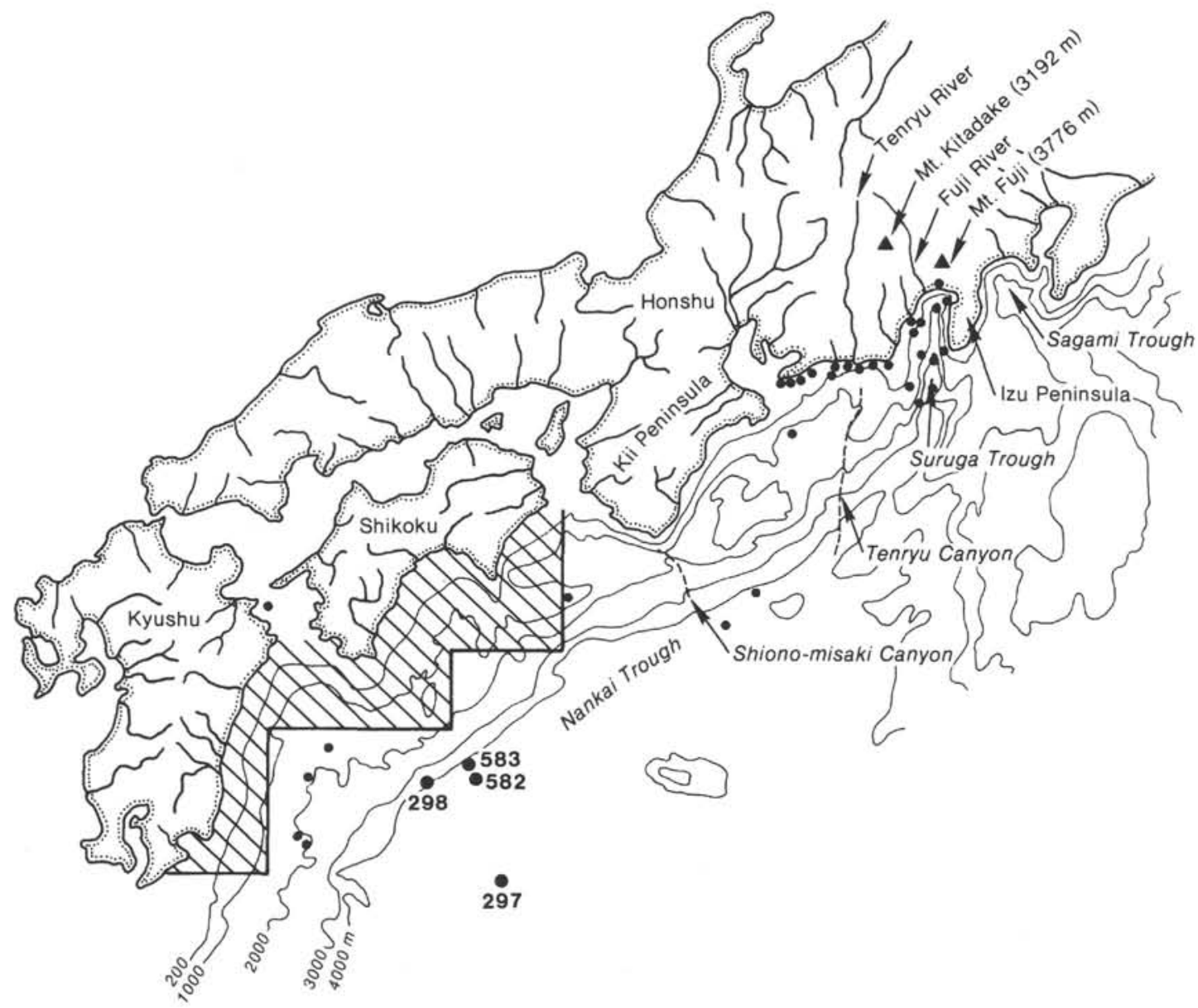

Figure 1. Location map for DSDP sites and reference samples. Shaded area indicates the area from which more than 500 samples were recovered. Dots locate piston core and grab samples.

Magnetic susceptibility was measured using a ring-core type fluxgate spinner magnetometer at Shizuoka University (Koyama and Niitsuma, 1983). The applied magnetic field was $25 \mu \mathrm{T}$. The shape of the anisotropy ellipsoid is represented by

$$
q_{n}=-\log _{2} \frac{(K \max -K \text { int })}{(K \text { int }-K \min )}
$$

The ellipsoid is more oblate when $q_{n}$ is positive and more prolate when $q_{n}$ is negative.

\section{Settling Tube Analysis}

Photo-extinction settling tube analysis was used for grain-size analysis. The method has several advantages over other grain-size methods, especially in its accuracy and precision. For DSDP samples, which usually do not have substantial volume, this method is advantageous because it generally requires less than $2 \mathrm{~g}$. The settling tube at Kochi University is $20 \mathrm{~cm}$ in diameter and $200 \mathrm{~cm}$ in settling distance. The principle is essentially the same as described previously (Niitsuma, 1971; Taira and Scholle, 1977). In this study, the analysis was limited only to the coarser sediment fraction, the lower limit being $\log V=$ $-0.8(V=$ settling velocity in $\mathrm{cm} / \mathrm{s}$, about $4.5 \mathrm{phi})$.

\section{Petrographic Analysis}

About 50 of the plastic cube samples used for magnetic fabric analysis were impregnated in polyester resin, and thin sections were made for petrographic and grain-orientation analysis. At the same time, the sieved coarse fraction $(>75 \mu \mathrm{m}$ ) was examined using thin sections and a binocular microscope. Immersion of the coarse fraction in water re- veals various surface grain features such as color, surface morphology, and abrasion characteristics which were useful for provenance study. Grain point-counting was employed for petrographic analyses of thin sections of DSDP and other reference samples.

\section{PHYSIOGRAPHY AND BACKGROUND GEOLOGY}

\section{Physiography}

The Nankai Trough is a shallow trench and is the plate boundary between the Philippine Sea and Eurasian plates. As pointed out by Sugimura (1972) and Nakamura and Shimazaki (1981), the plate boundary extends northward to the Suruga Trough and then onshore at the mouth of the Fuji River. It then continues to the Sagami Trough (Fig. 1).

The landward side of the trench displays a series of well-developed outer-ridge and forearc basins (Fig. 2). Two conspicuous canyons, the Tenryu and Siono-misaki canyons, cut into the outer ridge down to the trough floor. Near the DSDP sites, the Ashizuri Canyon reaches the southwestern part of Shikoku and may provide one avenue for sediment yield to the DSDP sites. Overall, the submarine physiography suggests that most of the sediment in the Nankai Trough is provided along the 


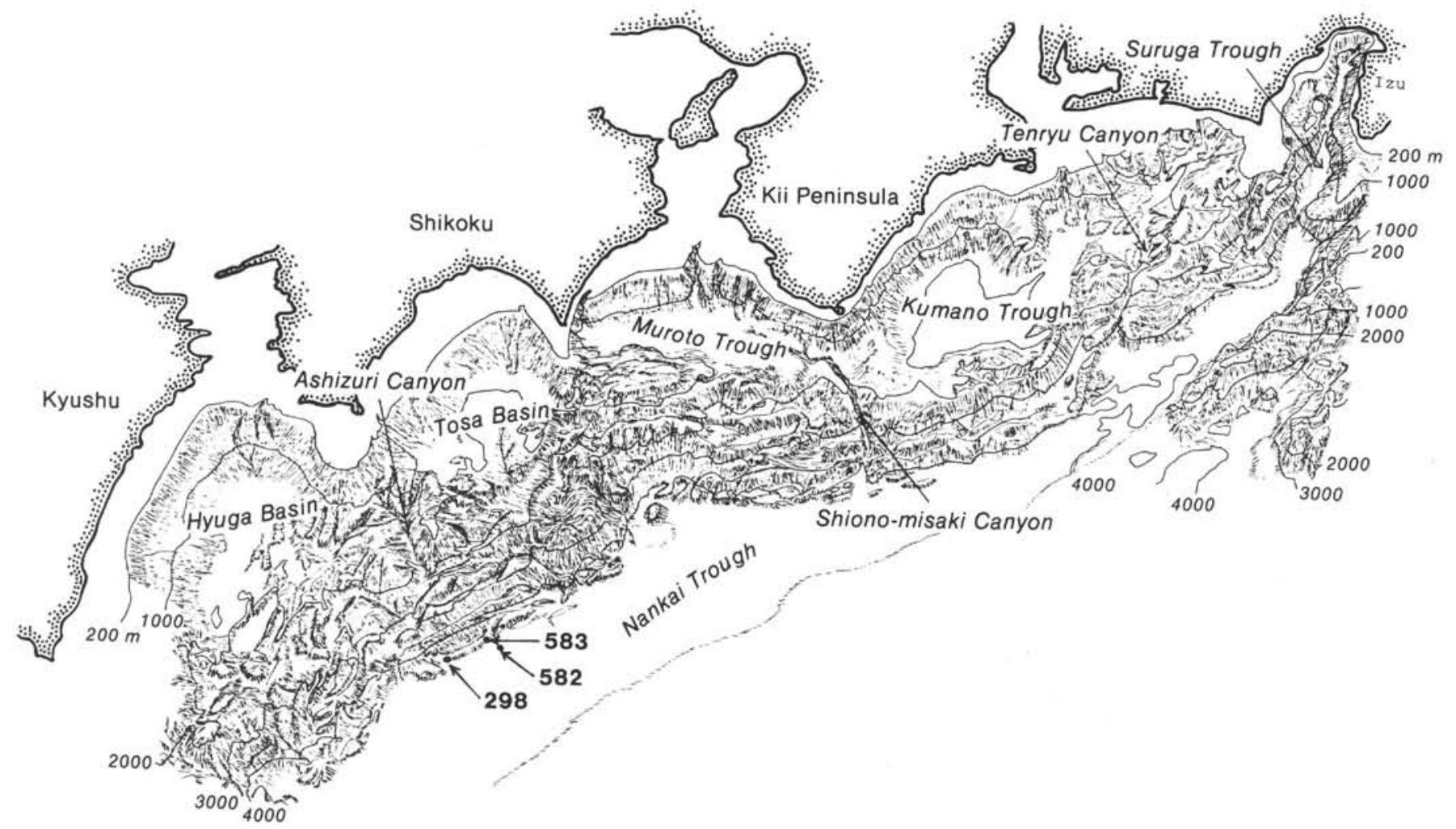

Figure 2. Submarine topography of the Nankai Trough and adjacent area (after Mogi, 1977).

axis of the trough, namely from northeast to southwest. The reasons are summarized below.

1. The Nankai-Suruga trough system is connected directly to the highest mountain ranges in Japan including the Akaishi Mountains and Mt. Fuji.

2. The drainage from these mountains flows directly into the Suruga Trough without forming large coastal plains.

3. The trough becomes markedly deeper and wider toward the southwest.

4. Longitudinal channels follow the floor of the trough (Mogi, 1977).

\section{Background Geology}

Subduction began at least as long ago as the Jurassic time and is responsible for the formation of the southwestern Japanese "basement" geology (Taira et al., 1983). Several geologic terranes, referred to as "belts" in Japanese terminology, are subparallel to the Nankai Trough. These belts are conspicuous and are classified into an inner and an outer zone, which are separated by Median Tectonic Line (Fig. 3).

The outer zone geology, which is closely related to the provenance of Nankai Trough clastics, is composed of three belts, the Sambagawa, Chichibu, and Shimanto belts. The Sambagawa Belt is made of high-pressure, metamorphic rocks probably representing a part of a Jurassic subduction complex. The Chichibu Belt is a heterogeneous geologic terrane, including a Jurassic subduction complex and a strike-slip mobile zone with exotic tectonic blocks. The dominant lithology is sandstone, slate, chert, limestone, and metabasalt. The Shimanto Belt represents a Cretaceous to Miocene subduction complex composed of sandstone, shale, chert, and metabasalt.

Neogene "post-Shimanto" sediments are limited to a few areas including the Miyazaki Group in Kyushu, the Tanabe-Kumano Group in the Kii Peninsula, and thick clastic sedimentary rocks in the southern Fossa Magna region.

The distribution of volcanic rocks seems to be a key to the evaluation of provenance. Tertiary-Quaternary volcanic rocks occur only in the Kyushu and Fossa MagnaIzu regions. Felsic to intermediate-type explosive activity represents the Kyushu volcanics, whereas mafic to intermediate volcanics are dominant in central Japan.

Neogene and Quaternary accretionary-complex and forearc-slope basin fill compose the offshore geology (Okuda, 1977; Taira, in press). Upper Pliocene sediments are widespread in the upper to lower slopes of the Nankai Trough region.

\section{LITHOLOGY}

\section{Lithology and Sedimentary Structures, Unit 1}

In the upper $300 \mathrm{~m}$ of Site 582 (Figs. 4 and 5), sedimentary structures are poorly preserved because of drilling deformation. The sequence below $300 \mathrm{~m}$ sub-bottom depth shows various types of sedimentary structures characteristic of turbidite sedimentation. Examples of turbidite beds are shown in Figures 6 and 7.

The sequence comprises four divisions: T1, T2, T3, and $\mathrm{H}$. The $\mathrm{T} 1$ division is composed of massive to graded sand. Sands are generally poorly sorted with mud content exceeding $10 \%$. Grain size ranges from very coarse 


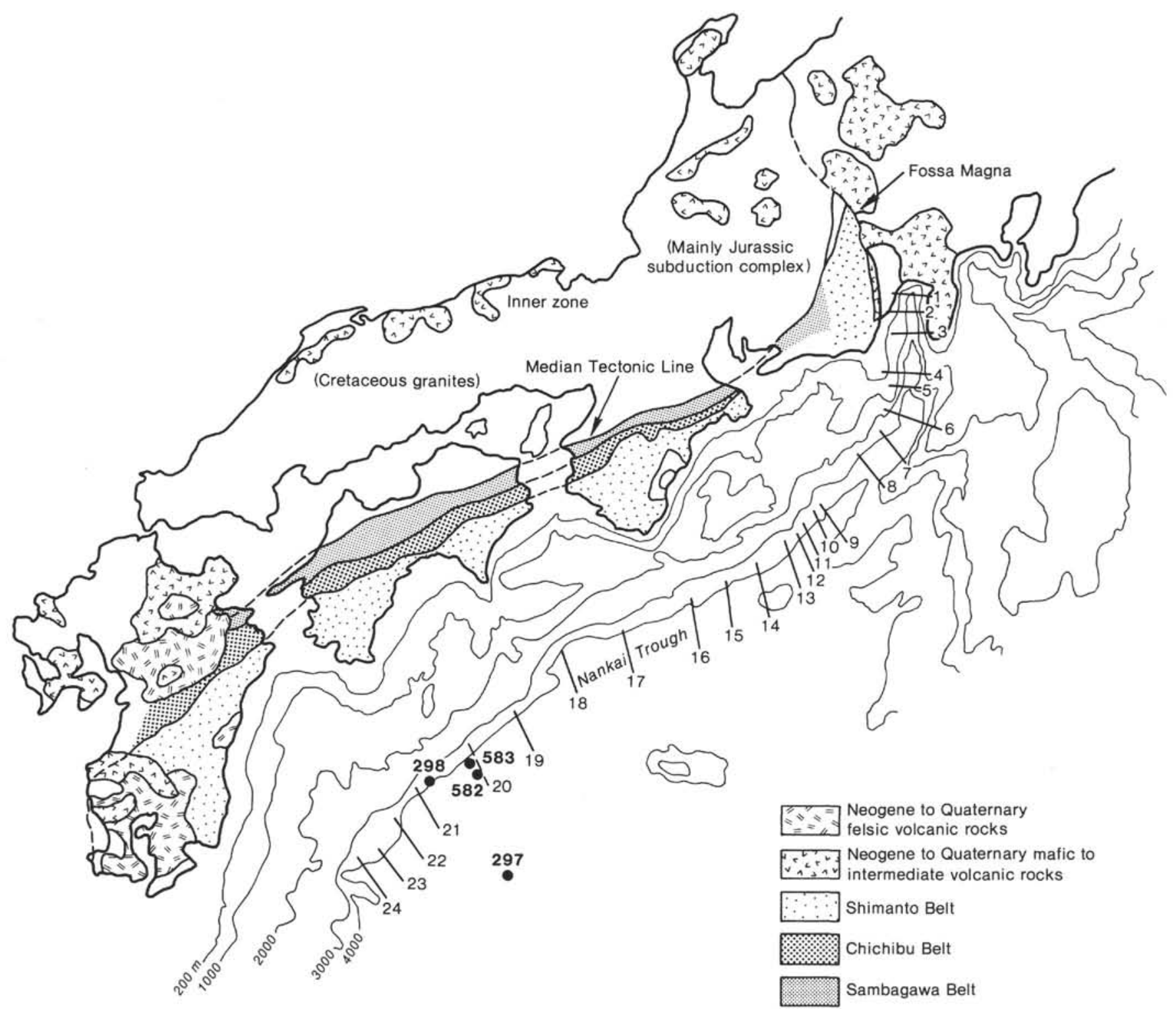

Figure 3. Map showing the major features of background geology related to the provenance of Nankai Trough turbidites. Lines numbered from 1 to 24 are topographic cross sections shown in Figure 23. Submarine contours are in meters.

to very fine grained sand but occasionally gravels were found. Pumice, plant fragments (including stems of land plants), and abraded gravels of siltstone were found in this division together with minor amounts of shells, echinoderms, and foraminiferal tests. The T2 division is finer grained (very fine sand to silt) and usually structureless, and parallel laminations are recognized occasionally in this part. In the Nankai Trough turbidites in general, ripple laminations are rare. The microfossil content increases uphole, especially calcareous nannoplankton which tend to concentrate at the uppermost part of this division, and consequently calcium carbonate content also increases. Fresh-water diatoms also occur. These observations indicate that Site 582 sands were emplaced from near-shore environments possibly very close to a river mouth. The T3 division is composed of silt with abundant Chondrites burrows. Burrows are 1-2 mm in diameter and darker in color, being filled with slightly finer-grained sediments. The $\mathrm{H}$ division is composed of blue greenish mud with fissility developed at the lower part of the Site 582 section. The mud is mottled by burrowing organisms. Smear-slide observations suggest that microfossils are scarce in this division. Calcareous nannoplankton are virtually absent, which is also indicated by low calcium carbonate content. We attribute this contrasting lithology between $\mathrm{T} 3$ and $\mathrm{H}$ division to the dissolution of calcium carbonate. The $\mathrm{H}$ division is inferred as a "background" of slow accumulation of hemipelagic mud below the calcite compensation depth (CCD).

Shipboard measurements of carbon content within a turbidite bed reveal that total carbon content decreases uphole whereas the organic carbon content stays essentially the same (Fig. 6). The trend of total carbon content thus reflects the uphole decrease of carbonate content as described above.

At Site 583, hydraulic piston coring revealed detailed sedimentary structures in a thinly bedded part of the upper part of Unit 1 . The turbidite beds observed are dif- 


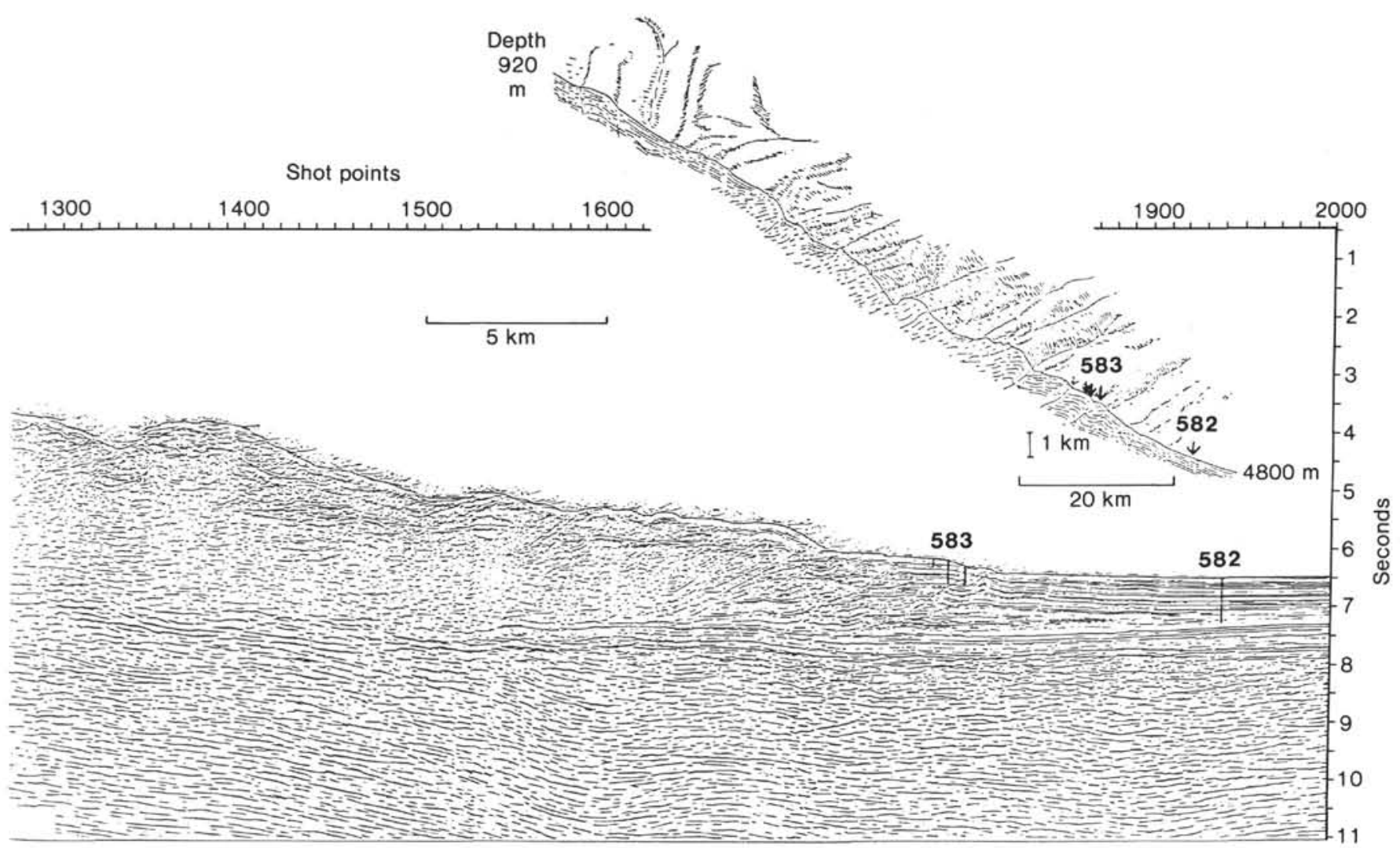

Figure 4. Migrated time section Line N55-3-1 showing Sites 582 and 583 (Nasu et al., 1982), and a block diagram of the submarine topography.

ferent from the lower part of Unit 1 of Site 582. As shown in Figure 8, the sequence is composed typically of three divisions: $\mathrm{T}^{\prime}{ }^{\prime}, \mathrm{T} 3^{\prime}$, and $\mathrm{H}$. The $\mathrm{T} 2^{\prime}$ division is composed of dark olive gray silt and very-fine-grained sand with parallel lamination. The $\mathrm{T} 3^{\prime}$ unit shows massive bedding of silty clay which contains microfossils. The $\mathrm{H}$ division is quite similar to the $\mathrm{H}$ division of the Site 582 sequence. The $\mathrm{T} 2{ }^{\prime}$ division can be correlated to the upper part of the T2 division, and the T3' division to the T3 division of the Site 582 sequence. Overall lithology suggests that the upper $50 \mathrm{~m}$ of the Site $583 \mathrm{se}$ quence was deposited by turbidity currents of lower concentration and lower flow-energy.

\section{Lithology and Sedimentary Structures, Unit 2}

Greenish blue hemipelagic mudstone is the dominant lithology encountered within Unit 2 at Site 582. Microfossils are generally less abundant compared with the turbidites of Unit 1 . However, local concentration of calcareous fossils indicates that the hemipelagite was deposited slightly above the CCD. Other features such as sedimentary structures are essentially the same as the $\mathrm{H}$ division of Unit 1. Planolites and Zoophycos burrows are abundant with ash-layer intercalations. Organic matter is concentrated in thin laminated layers. Unit 2 was originally deposited within the Shikoku Basin and then brought to the present position by plate movement.

\section{Bed-Thickness Distribution}

The bed-thickness distribution of turbidite sequences was examined for the intervals of relatively good recov- ery and preservation. At Site 582, the interval between Cores 582B-22 to 582B-44 was selected and at Site 583, Cores $583 \mathrm{~A}-1$ to $583 \mathrm{~A}-3$ were selected. Figure 9 shows histograms for turbidite bed thickness and hemipelagite (division $\mathrm{H}$ ) bed thickness distributions. The thickest turbidite bed observed is $105 \mathrm{~cm}$, and the mean value is $30.2 \mathrm{~cm}$. The mean thickness of the hemipelagite intercalations is $6.5 \mathrm{~cm}$ with maximum thickness of $20 \mathrm{~cm}$. In Hole 583A, the maximum thickness of the turbidite beds is $16 \mathrm{~cm}$ and the mean value is about $7 \mathrm{~cm}$.

Examination of bed-thickness distribution using a logprobability plot indicates that both selected intervals at Sites 582 and 583 show a log-normal distribution. Lognormality of turbidite bed thickness has been reported previously (e.g., Niitsuma, 1974), and several examples are shown for comparison (Fig. 10). Examples shown for comparison are Pleistocene turbidites of the Kokumoto Formation in the Boso Peninsula (distal channellevee association) and Eocene turbidites of the Shimanto Belt in Shikoku (both proximal and distal channellevee-overbank association). This comparison suggests that Site 582 turbidites are similar to distal channel-leveeoverbank association of ancient examples in their bed thickness distribution. On the other hand, the upper $50 \mathrm{~m}$ of Site 583 are more closely related to overbank settings only.

\section{Sedimentation Rate and Frequency of Turbidite Deposition}

The sediment accumulation rate at Site 582 was estimated based on paleontologic and magnetostratigraphic 


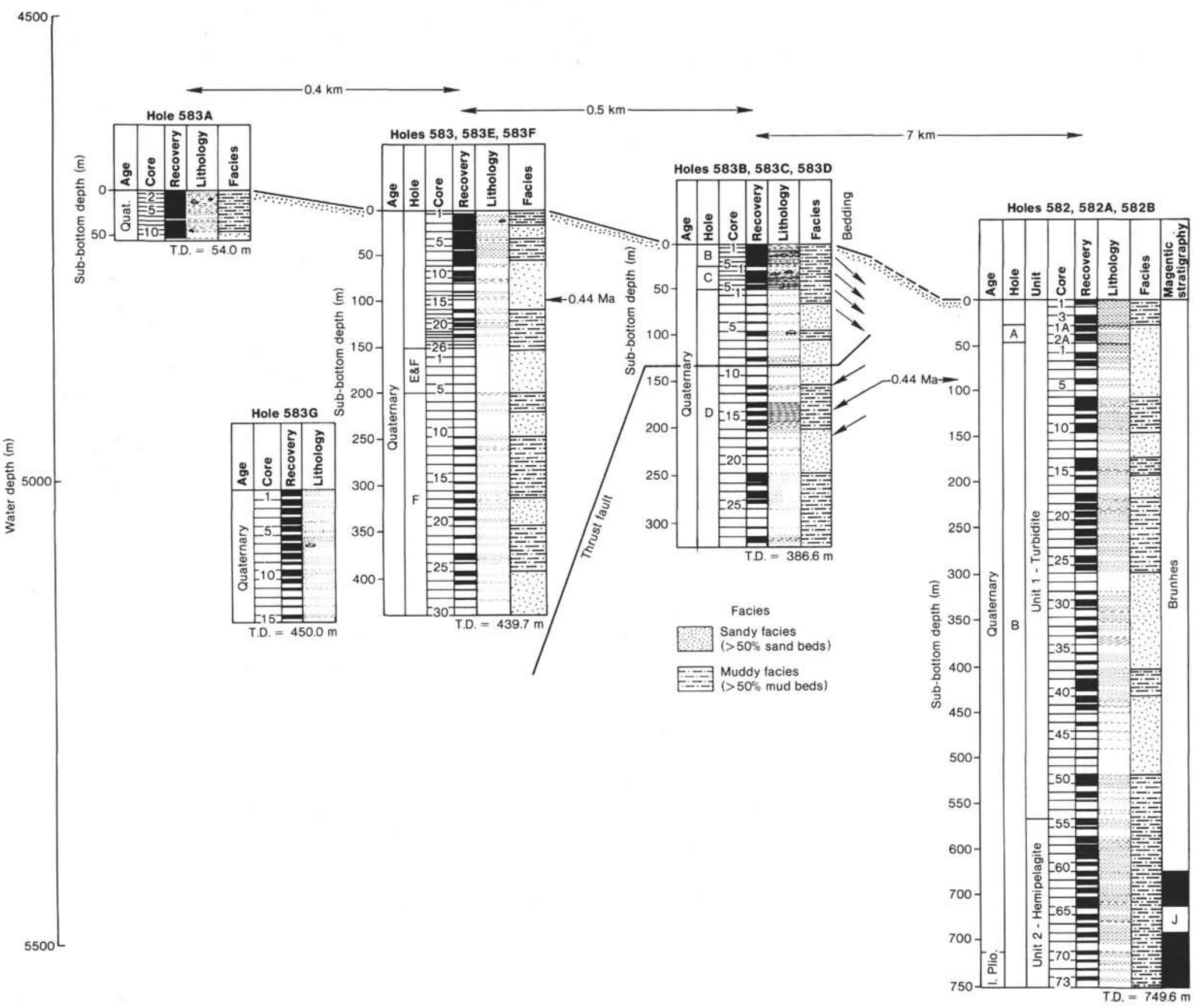

Figure 5. Lithology and correlation of Sites 582 and 583. T.D. = total depth. 


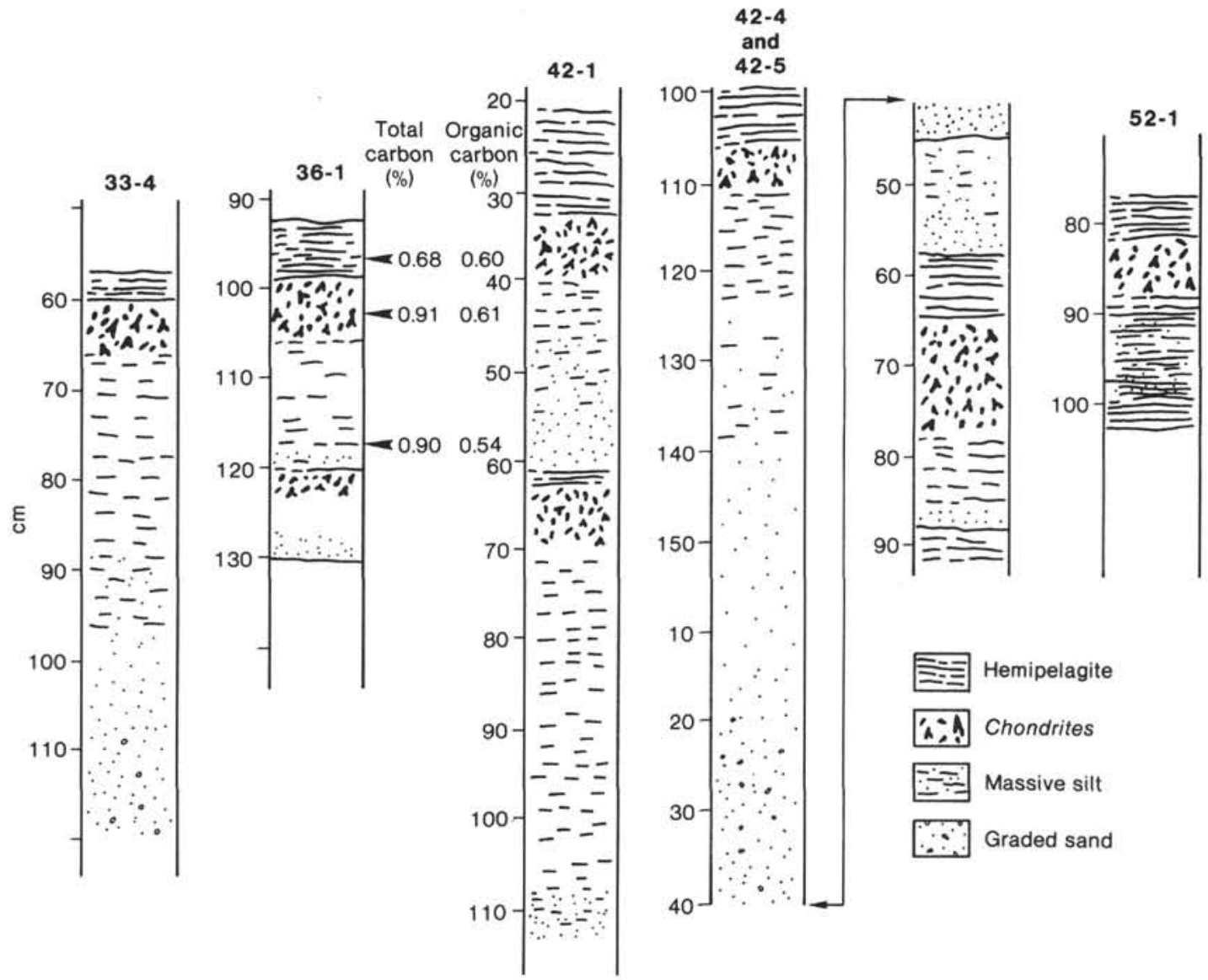

Figure 6. Turbidite sedimentary structures observed in Hole 582B. Locations expressed as core-section.

evidence (Fig. 11). The rate shows a remarkable variation. Within the upper part of Unit 1 (0-90 m sub-bottom depth), sediment accumulated at a rate of $200 \mathrm{~m} /$ $\mathrm{Ma}$, whereas in the lower part $(90-560 \mathrm{~m})$, it accumulated at a rate of $2000 \mathrm{~m} / \mathrm{Ma}$. This second value is comparable to the Pleistocene sedimentation of alluvial plains in Japan, an unusually high value for deep-sea sedimentation.

Assuming that turbidites were emplaced more or less instantaneously, we can infer that hemipelagite accumulation has taken up most of the time needed for sediment accumulation. If we take the mean values of 30.2 and $6.5 \mathrm{~cm}$ as representative thicknesses of turbidite and hemipelagite, respectively, each 6.5 -cm-thick hemipelagite accumulation in the lower part of Unit 1 represents about $200 \mathrm{yr}$. In the lower part of Unit 1, therefore, an average of $30 \mathrm{~cm}$ of turbidite was emplaced every $200 \mathrm{yr}$. Given that the average recurrence time of great historic earthquakes off southwestern Japan is on the order of 100 to 200 yr., a relationship between turbidite emplacement and major seismic events is likely.

\section{Summary of Turbidite Facies}

1. Sediment drilled at Sites 582 and 583 is divided into two units: turbidite facies (Unit 1) and hemipelagite facies (Unit 2). Unit 1 can be further divided into an upper finer-grained part (upper $50 \mathrm{~m}$ of 583) and a lower coarser-grained part.
2. Turbidites of Unit 1 can be summarized in a generalized facies model (Fig. 7).

3. The turbidite sequence at Site 582 shows a distal channel-levee-type bed-thickness distribution, and the upper $50 \mathrm{~m}$ of Site 583 may represent overbank depositional setting.

4. Turbidites were emplaced from nearshore river mouth environments.

5. The emplacement of turbidites was every $200 \mathrm{yr}$. The mean thickness of turbidite layers is $30 \mathrm{~cm}$ in the interval between 90-560 m sub-bottom depth.

\section{MAGNETIC FABRICS}

In DSDP cores, the original orientation of core specimens is completely lost because of drilling-induced rotation; however, if the direction of remanent magnetization is used as a magnetic compass, the specimens can be reoriented with reasonable accuracy. In this study, both remanent magnetization and anisotropy of magnetic susceptibility were measured on the same sample. The direction of magnetic fabric is presented relative to the magnetic north of the remanent magnetization (Table 1).

\section{General Features of Magnetic Fabric}

Many previous studies of the magnetic fabric on undeformed sediments have demonstrated that sediment shows a well-defined $K \min$ (minimum susceptibility) di- 

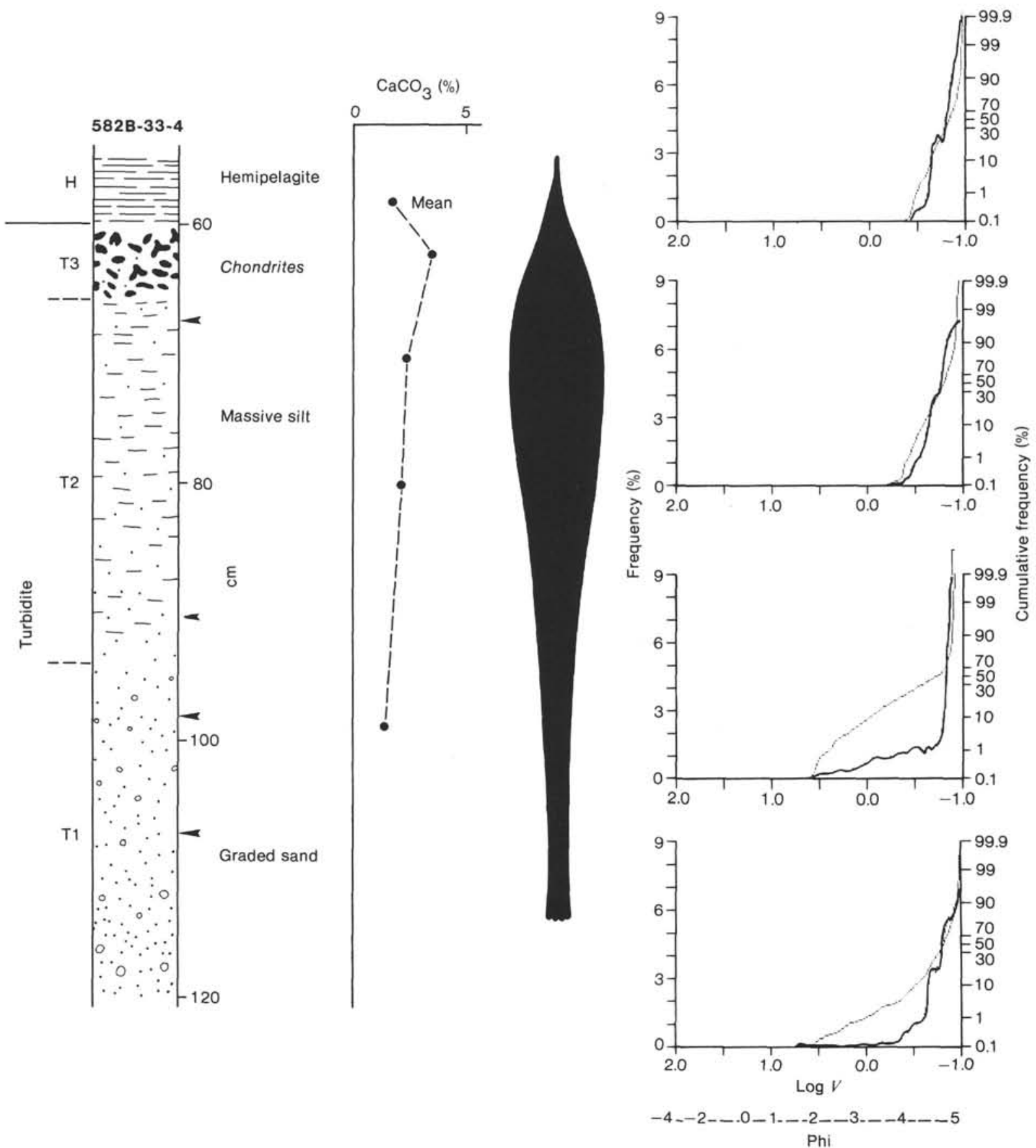

Figure 7. An example of a typical turbidite bed showing major observed features. Microfossil contents are shown on a relative scale in which the maximum content is $\sim 5 \%$. Right-hand column is grain-size distribution in frequency and cumulative frequency (solid line) curves plotted on a probability scale. Grain size is shown in $\log V(V=$ settling velocity; $\mathrm{cm} / \mathrm{s})$ with phi scale as reference.

rection subperpendicular to the bedding plane (Rees, 1965; Graham, 1966; Taira and Scholle, 1979). The inclination of $\mathrm{Kmin}$ direction usually lies within 90 to $60^{\circ}$ relative to the bedding plane, which is the angle of imbrication (Rees, 1965; Taira and Lienert, 1979).

The distribution of $K \max$ and $K \min$ directions on stereo-net are shown in Figures 12 and 13. The distribution of $K \mathrm{~min}$ directions of whole samples from Site 582 (Fig. 12A) suggests that, although many are concentrated around the pole of the bedding plane, a substantial number are at relatively low angles to the plane of bedding. These low-angle fabrics are generally regarded as "deformed fabric" and the following reasons are possible causes: (1) drilling-induced deformation; (2) synsedimentary deformation, such as slumping and bioturbation; and (3) tectonic deformation.

At Site 582, the effect of tectonic deformation is minimal because the beds are essentially flat-lying, and there is no sign of deformation indicated by any of the seismic profiles (Fig. 4).

The effect of both drilling deformation and bioturbation can be calibrated by comparing deformed and 


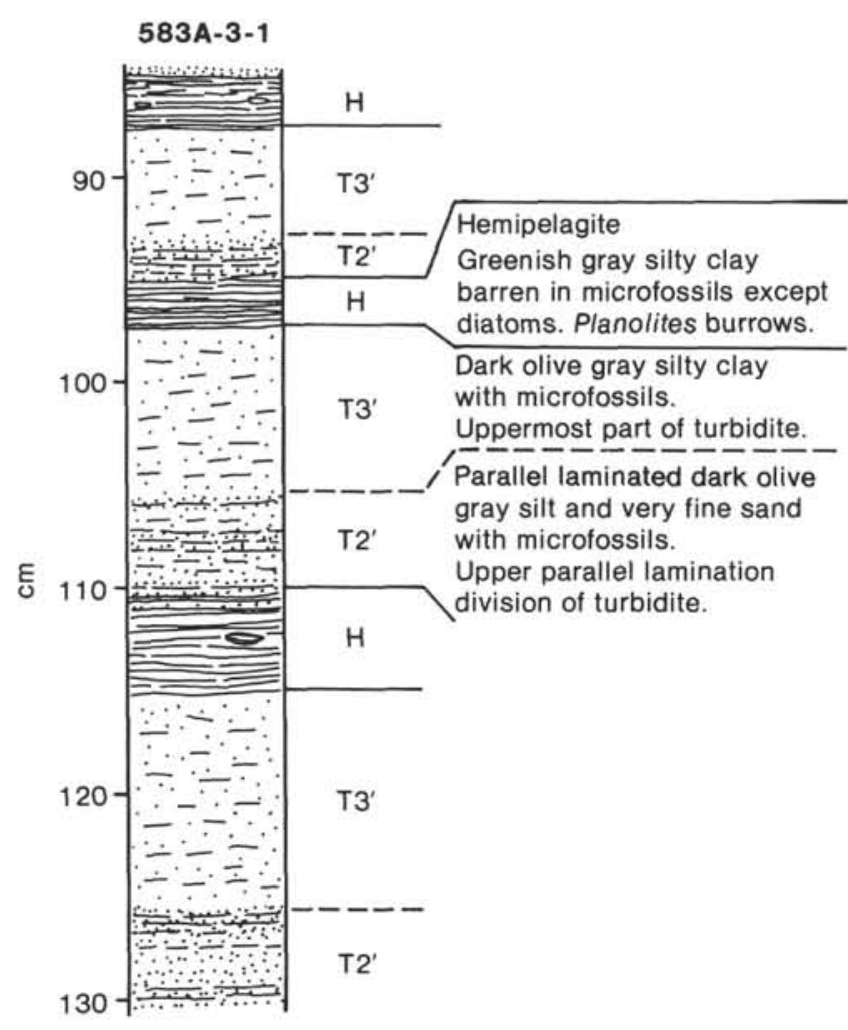

Figure 8. Turbidite sedimentary structures observed in Site 583 samples.
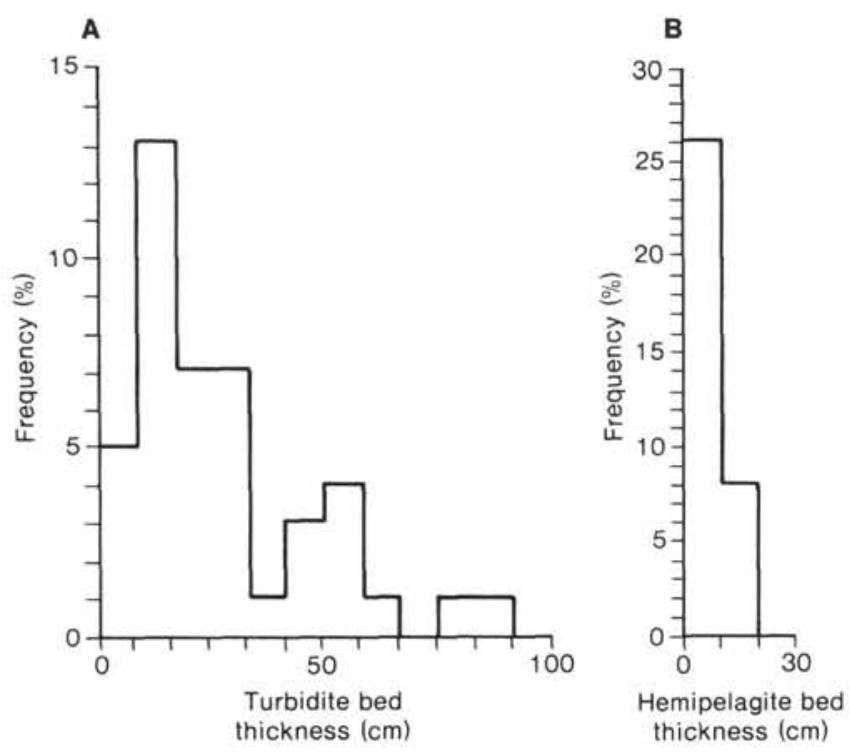

Figure 9. Bed-thickness distribution for the interval between Cores 582B-22 and 582B-44. A. Turbidite bed thickness, total of 43 beds, mean thickness $=30.2 \mathrm{~cm}$. B. Hemipelagite bed thickness, total of 34 beds, mean thickness $=6.5 \mathrm{~cm}$.

undeformed parts as shown in Table 2 and Figure 14. As expected, the $K \mathrm{~min}$ directions within the deformed part are more diverse than those within the undeformed part, suggesting that drilling deformation and bioturbation have altered the magnetic fabric. The effect of drilling deformation is also clear from Figure $12 \mathrm{C}$, which shows the well-grouped $K \min$ directions below $400 \mathrm{~m}$ sub-bottom depth where the sediments are apparently less deformed because of increased lithification. The $K \mathrm{~min}$ directions cluster around the pole of the bedding plane with a dominant inclination of imbrication angle toward the northeast.

The hydraulic piston cores of Site 583 are considerably deformed as far as their magnetic fabrics are concerned, although in appearance the bedding plane is fairly well preserved (Fig. 12D). We believe this is because very soft sediments recovered by the piston core were deformed during coring, core-splitting, and sampling.

\section{Paleocurrent Analysis}

As the direction of $K \max$ is approximately parallel to the long axis orientation of grains and $K$ min defines the imbrication, magnetic fabric is a useful indicator of paleocurrent direction (Rees, 1965; Taira and Scholle, 1979). For paleocurrent analysis, samples with a $K$ min direction of less than $60^{\circ}$ inclination were discarded. Also, because the majority of samples taken from the interval between 0 to $200 \mathrm{~m}$ sub-bottom depth are deformed, that interval was not taken into consideration.

Figure 15 shows the magnetic fabric at Site 582 below $200 \mathrm{~m}$ sub-bottom depth. Sandy and muddy intervals have contrasting magnetic susceptibility directions: $K \max$ is concentrated around the southwest and the declination of $K \mathrm{~min}$ around the northeast for sandy intervals, whereas the muddy intervals have more scattered $K$ max directions. Thus, paleocurrent direction indicated from the magnetic fabric runs predominantly from northeast to southwest, or parallel to the axis of the Nankai Trough.

The magnetic fabric of a single turbidite also supports this conclusion. A 60 -cm-thick turbidite from Section 582B-33-4 was sampled, and the magnetic fabric analysis suggests that this bed was transported from northeast to southwest (Fig. 16).

In order to further investigate this conclusion, grain orientations in thin sections were counted according to standard procedures. Results with vectors of magnitude of less than $15 \%$ were not included in the data presentation (Fig. 17). Magnetic fabric and grain counts correlate well. The mean direction of grain-counting analysis from 16 thin sections shows that the paleocurrent direction of turbidity currents is northeast to southwest.

\section{Comparison between Sites 582 and 583}

Magnetic fabric data obtained from Site 583 suggests that there is a slight difference in the distribution pattern of $K \mathrm{~min}$ directions compared with the Site 582 data. $K \mathrm{~min}$ at Site 582 is concentrated around $30^{\circ}$ declination and $80^{\circ}$ inclination, an indication of current-imbricated pattern (Fig. 12C). At Site 583, Kmin shows a girdle-type distribution around a N30W-S30E great circle (Fig. 12B). The pattern of $K \max$ distribution, on the other hand, is similar for both (Fig. 13).

A possible explanation for the great circle distribution of $K \mathrm{~min}$ direction at Site 582 is induced tectonic stress. Graham (1966) presented a model for deformation of original depositional fabric during the early stages of sediment dehydration in Appalachian sedimentary 


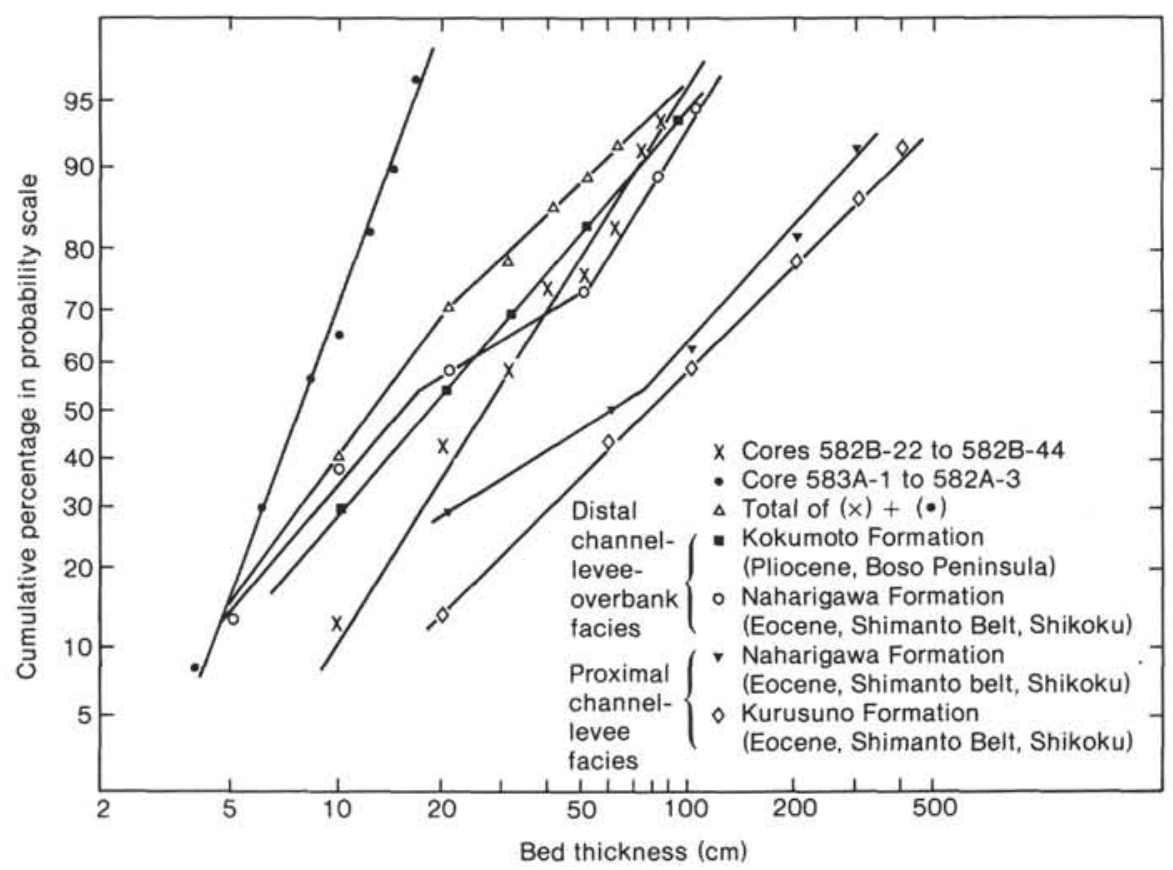

Figure 10. Log-probability plots of turbidite-bed-thickness distributions for various examples.

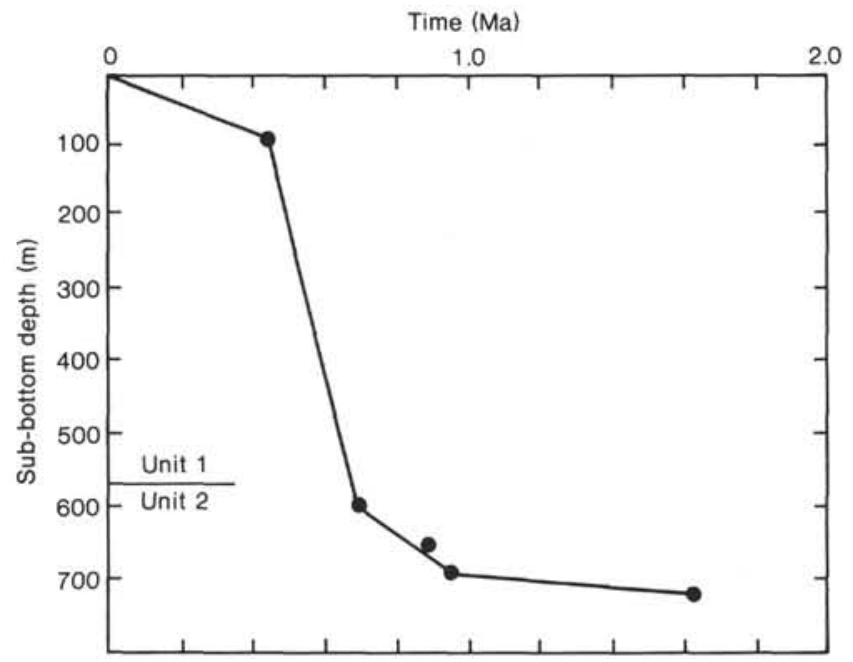

Figure 11. Sediment accumulation rates at Site 582.

rocks. The data obtained from Site 583 can be explained by a similar model; namely, the $K \min$ direction was rotated slightly because of the northwest-southeast compressional stress without significantly changing the $K \max$ direction. Also, the value of $q_{n}$ is negative at Site 583, suggesting that the fabric is more prolate (Fig. 12A, B). Seismic profiles (Nasu et al., 1982) reveal an apparent shortening and thickening of sediments between the two sites. From these observations, it is suggested that the rotation and reorientation of the short axis of sedimentary grains might have taken place between Sites 582 and 583. If this inference is justified by further data from other places, such reorientations may provide a means of identifying tectonic stress in ancient accretionary prisms. The interpretation of magnetic fabrics is summarized in Figure 18.

\section{GRAIN-SIZE ANALYSIS}

Photo-extinction settling tube analysis of 50 turbidite samples from DSDP sites and 250 samples from the area offshore of Shikoku and Kyushu (Fig. 1) were carried out.

\section{Grain-Size Characteristics of Turbidites}

Several examples of grain-size data from Site 582 are presented in Figure 7, and additional examples are shown in Figure 19. The following characteristics are noteworthy:

1. Grain sizes are generally poorly sorted, and distributions lack a notable modal peak.

2. Grading, which is indicated by a gradual decrease of coarse-tail grain size (coarse-tail grading), is observed.

3. Two basic grain-size patterns occur in the $\mathrm{T} 1$ and $\mathrm{T} 2$ divisions of turbidite beds, respectively. A longer and well-developed coarse tail characterizes the T1-division type, whereas a poorly developed coarse tail distinguishes the T2-division type. Generally, there is a break between the two; in other words, these types do not show a gradual change.

The Nankai grain-size distributions differ from the Pliocene Pico Formation, Ventura Basin of California, and from the Pleistocene Kokumoto Formation, Boso Peninsula of Japan (Fig. 19). The Site 582 and 583 turbidites are characterized by a lack of current-sorted distribution. Taira and Scholle (1979) suggested that graded division of a turbidite is emplaced by highly concentrated non-Newtonian mass flow, whereas the part above is deposited by less concentrated Newtonian density (turbidity) current. The break in grain-size characteristics between graded division and the above division is a consequence of this difference in flow characteristics. This break in grain-size characteristics is not as clear for the turbidites of Sites 582 and 583 as for turbidites from 
Table 1. Examples of magnetic anisotropy, Hole 582B.

\begin{tabular}{|c|c|c|c|c|c|c|c|c|c|c|}
\hline \multirow[b]{2}{*}{$\begin{array}{c}\text { Core-Section } \\
\text { (interval in cm) }\end{array}$} & \multicolumn{3}{|c|}{$\begin{array}{c}\text { Maximum } \\
\text { susceptibility }\end{array}$} & \multicolumn{3}{|c|}{$\begin{array}{l}\text { Intermediate } \\
\text { susceptibility }\end{array}$} & \multicolumn{3}{|c|}{$\begin{array}{c}\text { Minimum } \\
\text { susceptibility }\end{array}$} & \multirow[b]{2}{*}{$q_{n}$} \\
\hline & $\underset{\left(\times 10^{-3}\right)}{K \max }$ & $D$ & $I$ & $\underset{\left(\times 10^{-3}\right)}{K \text { int }}$ & $D$ & $I$ & $\underset{\left(\times 10^{-3}\right)}{K \min }$ & $D$ & $I$ & \\
\hline $41-5,59-61$ & 16.4 & 104 & -2 & 15.8 & 194 & -8 & 15.2 & 2 & -82 & -0.04 \\
\hline $41-5,76-78$ & 42.6 & 224 & -18 & 41.9 & 317 & -8 & 41.2 & 69 & -70 & -0.13 \\
\hline $41-5,97-99$ & 46.9 & 302 & -16 & 45.8 & 209 & -8 & 44.7 & 96 & -72 & 0.02 \\
\hline $42-1,40-42$ & 9.96 & 116 & -11 & 9.92 & 23 & -9 & 9.58 & 255 & -75 & 3.32 \\
\hline $42-1,53-55$ & 11.6 & 109 & -1 & 11.4 & 199 & -6 & 10.7 & 11 & -84 & 2.23 \\
\hline $42-2,81-83$ & 12.8 & 193 & -4 & 12.5 & 103 & -5 & 11.7 & 317 & -84 & 1.48 \\
\hline $42-2,118-120$ & 4.86 & 213 & -22 & 4.63 & 117 & -15 & 4.52 & 354 & -63 & -1.02 \\
\hline $42-4,5-7$ & 36.0 & 284 & -10 & 35.0 & 189 & -29 & 34.5 & 31 & -59 & -0.96 \\
\hline $42-4,63-64$ & 47.6 & 241 & -18 & 47.1 & 145 & -16 & 45.2 & 18 & -65 & 2.01 \\
\hline $42-5,32-35$ & 29.8 & 310 & -3 & 29.5 & 41 & -2 & 28.7 & 170 & -86 & 1.44 \\
\hline $44-2,40-42$ & 9.54 & 208 & -6 & 9.17 & 97 & -74 & 9.12 & 299 & -15 & -2.92 \\
\hline $44-2,53-55$ & 20.5 & 149 & -6 & 19.8 & 58 & -8 & 18.2 & 272 & -80 & 1.44 \\
\hline $50-1,41-43$ & 13.6 & 180 & -10 & 12.4 & 89 & -4 & 11.9 & 337 & -79 & -1.35 \\
\hline $50-2,54-56$ & 32.3 & 229 & -7 & 29.4 & 139 & -3 & 25.5 & 24 & -82 & 0.49 \\
\hline $50-3,73-75$ & 1.45 & 281 & -1 & 0.91 & 191 & -16 & 0.662 & 16 & -74 & -1.13 \\
\hline $50-7,15-17$ & 16.9 & 156 & -7 & 16.7 & 63 & -25 & 15.7 & 259 & -64 & 1.89 \\
\hline $51-1,58-60$ & 3.50 & 282 & -11 & 3.06 & 16 & -22 & 2.85 & 168 & -65 & -1.10 \\
\hline $51-1,62-63$ & 11.8 & 89 & -4 & 11.2 & 181 & -34 & 10.9 & 353 & -56 & -0.63 \\
\hline $52-1,101-103$ & 65.9 & 61 & -3 & 65.8 & 331 & -3 & 62.3 & 203 & -86 & 5.48 \\
\hline $52-1,94-96$ & 9.81 & 143 & -3 & 8.53 & 234 & -12 & 6.55 & 40 & -78 & 0.63 \\
\hline $52-3,60-62$ & 54.1 & 281 & -1 & 52.8 & 11 & -9 & 50.5 & 183 & -81 & 0.84 \\
\hline $52-3,79-81$ & 108.0 & 71 & -2 & 106 & 340 & -7 & 101.0 & 175 & -83 & 1.32 \\
\hline $52-3,4-6$ & 61.3 & 122 & -3 & 60.4 & 32 & -4 & 54.0 & 254 & -85 & 2.82 \\
\hline $54-2,58-60$ & 15.5 & 268 & -3 & 13.8 & 177 & -11 & 12.1 & 11 & -79 & -0.06 \\
\hline
\end{tabular}

Note: $D=$ declination (in degrees, $360^{\circ}$ clockwise; $0^{\circ}=$ magnetic north); $I=$ inclination (in degrees, negative upward; $0^{\circ}=$ horizontal).

other areas. This observation, together with a lack of well-developed parallel and ripple lamination is a unique characteristic of the Nankai Trough turbidites. The reason is uncertain-perhaps the grain size of sediments above the T1 division is usually too fine-grained to form either flat beds or current ripples. The turbidites were emplaced as muddy, highly concentrated non-Newtonian flow with less-developed diluted secondary flow.

\section{Grain-Size Distribution in the Surrounding Area}

It is not within the scope of this report to describe all available data; however, the following facts pertain to the provenance and transport direction of turbidites.

Available data on the grain size of sediments offshore southwestern Japan (mainly from the shaded area in Fig. 1) can be classified into three basic types: (1) nearshore to shelf, (2) slope, and (3) base of slope or trough (Fig. 20). Type 1 shows a well-developed peak suggestive of sorting processes. Type 2 is a composite type with bimodal or multimodal peaks and occasionally large mud content. Type 3 is characterized by a lack of modal peaks and by a large mud content.

Sediments offshore of Shikoku are generally fine grained; coarse clastics are limited to the nearshore environments. The Ashizuri Canyon sediments also have basically Type 2 patterns, and there is no sign of emplacement of a large quantity of nearshore sands along the canyon axis.

A phenomenal exception is recognized at the Suruga trough area where a large volume of nearshore sands is emplaced. Type 1 grain-size distribution occurs in the Suruga Trough at depths exceeding $3000 \mathrm{~m}$.
Paleocurrent analysis of Nankai Trough turbidites suggests, as mentioned above, transport from northeast to southwest along the axis of the Nankai Trough, and the comparison of the few available samples shows a notable grain-size change along strike (Fig. 21). In piston core KH-72-2-21, located south of the Kii Peninsula, graded beds are coarser grained and apparently have a better sorted distribution than at Site 582. Sample KT78-19-24, which is in the Suruga Trough, contains wellsorted medium sand. Other piston core locations, in the Suruga Trough include much coarser-grained sands and gravels (Sato, 1962; Ohtsuka, 1980). This lateral change in grain-size and sorting characteristics along the NankaiSuruga Trough supports the northeast to southwest flow pattern deduced from the grain-orientation analysis.

\section{DETRITAL MODAL ANALYSIS}

The above discussion indicates that the turbidites at Sites 582 and 583 were transported from northeast to southwest along the axis of the Nankai Trough. In order to track down the exact provenance, it was necessary to carry out a petrographic analysis.

\section{Compositional Characteristics of the Turbidite Sands}

The following features characterize the composition of the turbidite sands.

1. As mentioned previously, sands at Sites 582 and 583 include abundant land-derived materials such as plant debris and fresh-water diatoms. On the other hand, marine organisms are less abundant, especially in the sandy part. The available reference samples from offshore of southwestern Japan indicate that most of the marine sands 

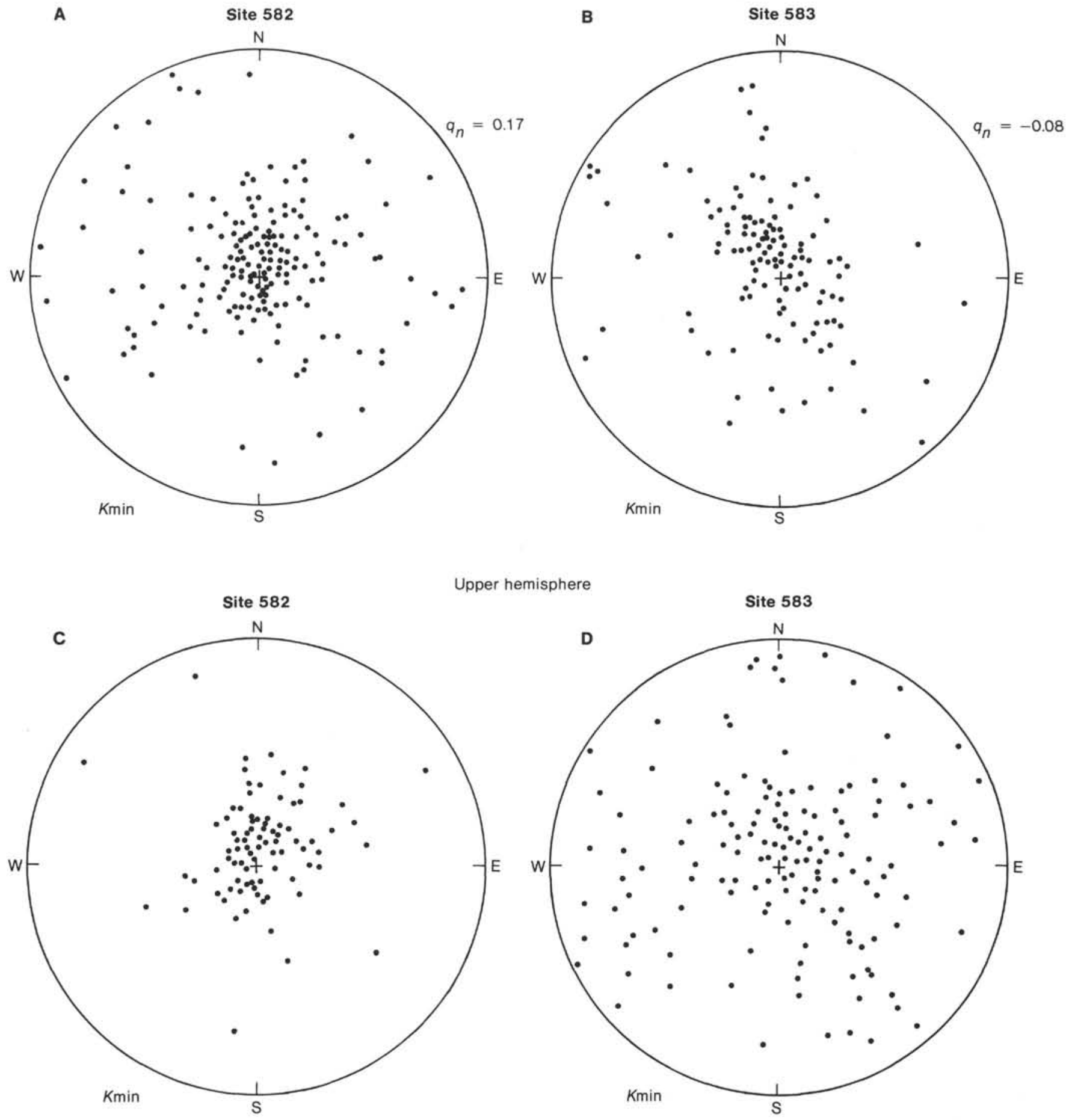

Figure 12. Kmin directions of Site 582 and 583 samples. A. Site $582,66-442 \mathrm{~m}$ sub-bottom depth. B. Site $583,66-442 \mathrm{~m}$ sub-bottom depth. C. Site 582 below $400 \mathrm{~m}$ sub-bottom depth. D. Site 583 HPC cores. Mean values of $q_{n}$ are shown in A and B.

are rich in skeletal debris of marine organisms such as molluscan shells and foraminiferal and echinoderm fragments. These components suggest that most of the sands were directly derived from river mouths, not from much older shelf deposits.

2. The most abundant detrital components are black slate, sandstone, and chert. These sedimentary rock fragments are probably derived from the outer zone of geologic belts, such as the Shimanto and Chichibu belts.
3. Especially noteworthy is the presence of a substantial volcanic component, including volcanic rock fragments, pumice, and volcanic glass, plagioclase, pyroxene, and olivine. Examination under both polarizing and binocular microscopes reveals both basic and intermediate volcanic rock fragments; some of these are red in color. These volcanic grains are critical for provenance determination, because the distribution of volcanic rocks is limited to two areas in the outer zone of southwestern 

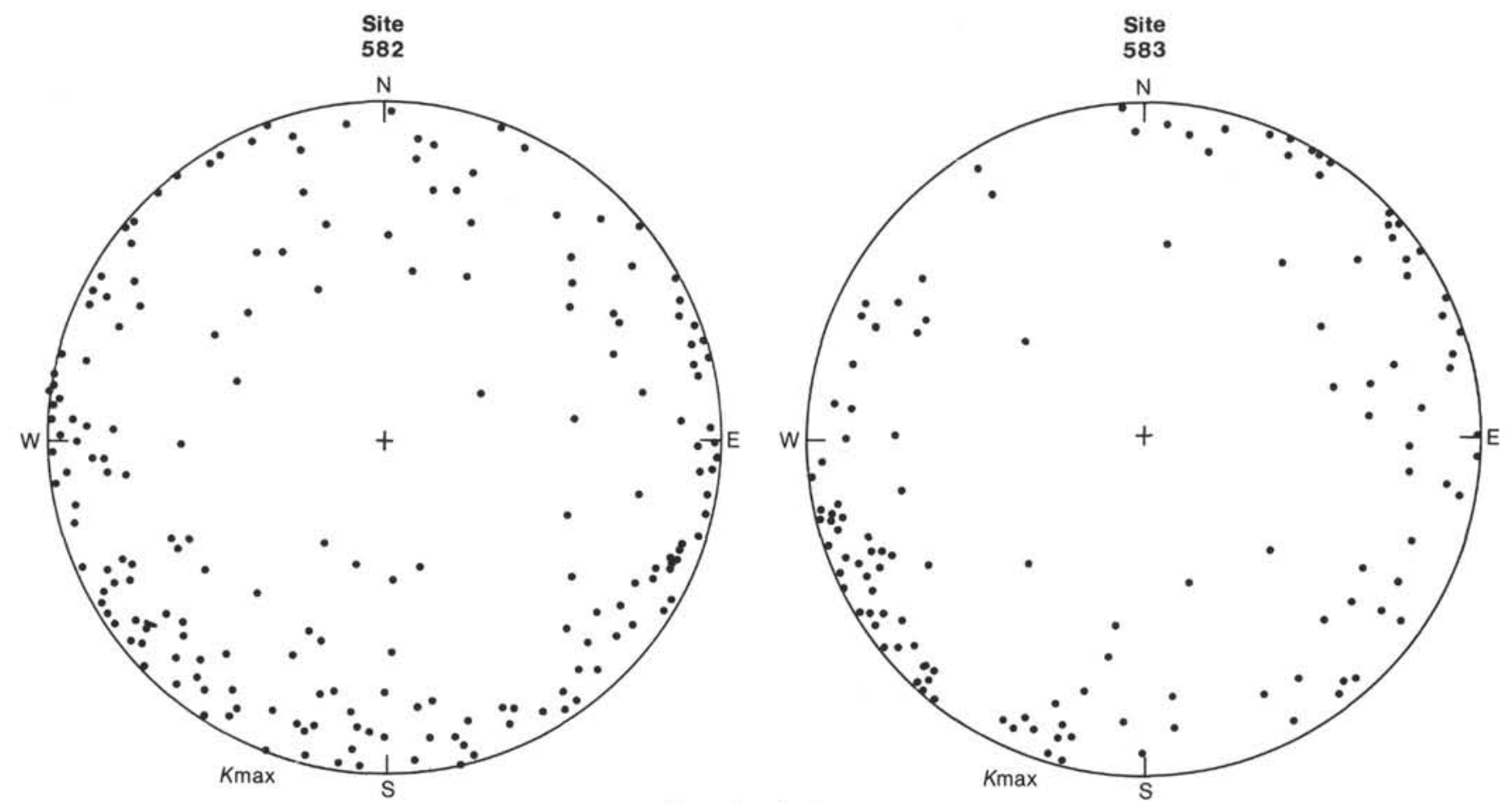

Upper hemisphere

Figure 13. Kmax direction for Sites 582 and 583.

Table 2. Calibration for deformation of magnetic fabric, Hole 583D.

\begin{tabular}{|c|c|c|c|c|c|c|c|c|c|c|}
\hline \multirow[b]{2}{*}{$\begin{array}{l}\text { Core-Section } \\
\text { (interval in cm) }\end{array}$} & \multicolumn{3}{|c|}{$\begin{array}{l}\text { Maximum } \\
\text { susceptibility }\end{array}$} & \multicolumn{3}{|c|}{$\begin{array}{l}\text { Intermediate } \\
\text { susceptibility }\end{array}$} & \multicolumn{3}{|c|}{$\begin{array}{l}\text { Minimum } \\
\text { susceptibility }\end{array}$} & \multirow[b]{2}{*}{$q_{n}$} \\
\hline & $\underset{\left(\times 10^{-3}\right)}{K \max }$ & $D$ & $I$ & $\begin{array}{c}K \text { int } \\
\left(\times 10^{-3}\right)\end{array}$ & $D$ & $I$ & $\underset{\left(\times 10^{-3}\right)}{K \min }$ & $D$ & $I$ & \\
\hline $22-1,77-79$ & 23.9 & 143 & -3 & 23.7 & 52 & -17 & 22.0 & 242 & -73 & 3.18 \\
\hline $22-2,123-125$ & 15.3 & 134 & -47 & 14.7 & 22 & -19 & 14.6 & 277 & -37 & -1.99 \\
\hline $22-3,47-49$ & 19.1 & 198 & -18 & 18.8 & 99 & -22 & 17.2 & 322 & -60 & 2.00 \\
\hline $22-3,110-112$ & 6.07 & 244 & -20 & 5.69 & 335 & -3 & 5.08 & 74 & -69 & 0.69 \\
\hline $22-4,67-69^{\mathrm{a}}$ & 5.38 & 152 & -3 & 5.05 & 60 & -36 & 4.74 & 246 & -53 & -0.06 \\
\hline $22-4,70-72^{\mathrm{a}}$ & 2.58 & 154 & -59 & 2.25 & 282 & -19 & 2.12 & 21 & -22 & -1.32 \\
\hline $22-5,61-63^{b}$ & 7.30 & 77 & -41 & 6.74 & 309 & -35 & 6.04 & 195 & -30 & 0.32 \\
\hline $22-5,68-70$ & 17.2 & 232 & -11 & 16.3 & 137 & -24 & 15.0 & 347 & -64 & 0.66 \\
\hline $22-6,49-51$ & 25.0 & 69 & -5 & 23.3 & 161 & -20 & 21.3 & 326 & -69 & 0.30 \\
\hline
\end{tabular}

Note: $D=$ declination (in degrees, $360^{\circ}$ clockwise; $0^{\circ}=$ magnetic north); $I=$ inclination (in degrees, negative upward; $0^{\circ}=$ horizontal).

a Drilling-induced deformation.

Japan; one is in Kyushu and the other is in central Japan.

4. Other components include micas, hornblende, and some metamorphic minerals such as alkaline amphiboles. The first two are possibly derived from a granitic terrane. These minerals are also diagnostic of provenance.

\section{Provenance of the Turbidite Sands}

Point counting was used to investigate and compare the detrital components of the sands at Sites 582 and 583 and surrounding areas (Table 3 ). A special combination of end-member components was devised to discriminate the outer zone sediments of southwestern Japan:
1. Component $\mathrm{OZ}$ (outer zone background) includes sandstone, shale, chert, and metamorphic rock fragments, which are derived from "basement" geologic terranes of the outer zone of southwestern Japan, such as the Shimanto, Chichibu, and Sambagawa belts.

2. Component AV (acidic volcanic) includes plagioclase, pyroxene, glass, and pumice, which are derived mostly from eruptive acidic to intermediate pyroclastic flows.

3. Component VR (volcanic rock fragments) includes volcanic rock fragments, in particular, red, brown, and black fragments, which are mostly intermediate to basic in composition. 


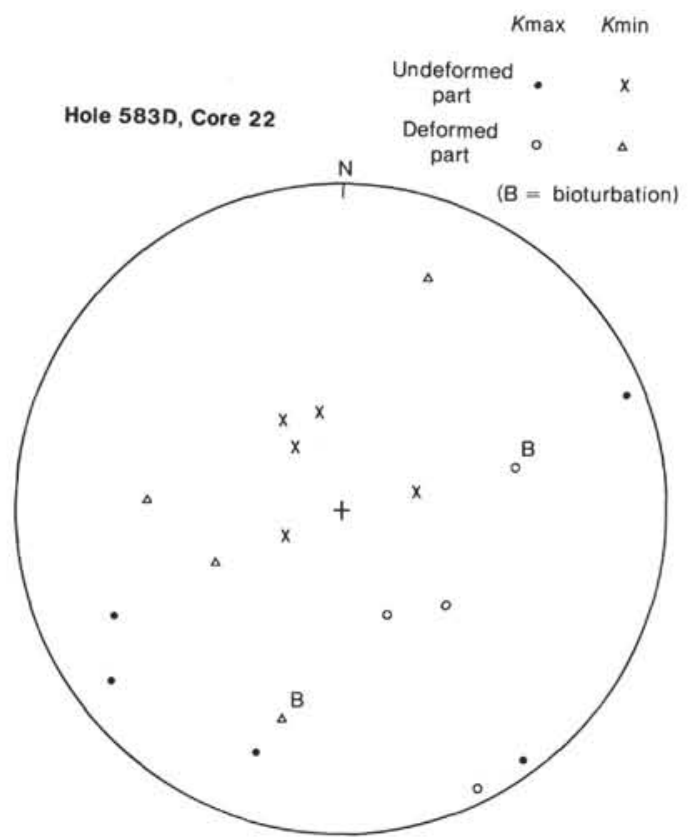

Figure 14. Calibration for drilling and burrowing disturbance on magnetic fabrics.

The AV component is closely related to the Quaternary volcanic rocks of Kyushu such as the Aso and Aira volcanics. The VR component is related to the volcanic rocks of central Japan and to the Tertiary volcanic rocks in Kyushu.

A ternary plot of OZ-AV-VR components together with a conventional $\mathrm{Q}$ (quartz)-F(feldspar)-R(rock fragment) plot is shown in Figure 22. Generally, sands of the outer zone of southwestern Japan are classified as lithic wackes or lithic greywackes (Fig. 22A). Sands from the Kyushu area are more feldspathic than others.

The OZ-AV-VR ternary plot clearly discriminates the sands of the outer zone of southwestern Japan into four compositional provinces (Fig. 22B). Sands from Kyushu are rich in the AV component, sands from Shikoku are virtually devoid of volcanic components, and sands from Tokai are slightly more feldspathic than those from Shikoku. Sands at DSDP sites, other areas of the Nankai Trough, the Suruga Trough, and the Fuji River area are almost identical.

The composition of Site 298 sands (Harrold and Moore, 1975) is essentially the same as the sands at Sites 582 and 583 (Fig. 22).

The detrital components, grain-size distributions, and magnetic fabric together with physiographic observations suggest strongly that the sands of Sites 582 and 583 were derived from the mouth of the Fuji River trough, the Suruga Trough, and along the axis of the Nankai Trough, involving a transport distance of $700 \mathrm{~km}$.

\section{SEDIMENTARY FACIES AND SEDIMENTATION MODEL}

\section{Sediment Budget}

The sedimentation rate based on magnetobiostratigraphy indicates an enormous sediment yield rate in the interval from 0.6 to $0.4 \mathrm{Ma}$. Naturally, a fundamental question occurs regarding sediment budget; could the Fuji River drainage basin alone supply the sediments deposited in the Nankai Trough?

The present-day Nankai Trough area includes roughly $10,000 \mathrm{~km}^{2}$ of turbidite sedimentation area with a mean thickness of about $500 \mathrm{~m}$. The total volume of turbidites is thus $5000 \mathrm{~km}^{3}$. The Fuji drainage basin is about $5000 \mathrm{~km}^{2}$. Present-day erosional rates of central Japan, including the Ohi and Tenryu drainage basins, has been calibrated previously, based on artificial reservoir sedimentation rates (e.g., Kaizuka, 1977). The value is 5 to $6 \mathrm{~mm}$ per unit area per yr.

To provide $5000 \mathrm{~km}^{3}$ of sediment to the Nankai Trough within $0.2 \mathrm{Ma}$ requires $5 \mathrm{~mm}$ per unit area per yr., a unit rate almost identical to the present-day erosional rate. Of course, not all sediments eroded from the Fuji drainage basin were deposited as turbidites in the Nankai Trough. Considering additional sediment supply to the Suruga Trough by the Ohi, Abe, and Kano rivers and possible longshore transport from the Omaezaki area (sands of the Tenryu River), we may reasonably conclude that the magnitude of a drainage basin like that of the Fuji River is capable of producing enough sediment to account for the volume of the entire Nankai Trough turbidite sequence.

One problem concerning this evaluation is the role of Mt. Fuji. The maximum age of this gigantic volcano is about $0.08 \mathrm{Ma}$, which postdates the period of maximum sediment supply. The configuration of the paleo-Fuji drainage system before the existence of Mt. Fuji is unknown and remains a subject for future study.

A longitudinal cross section from the Fuji River to the Nankai Trough reveals that the proximal part of this sediment transport system has a high gradient (Fig. 23). From the summit of Mt. Kitadake, the second highest peak (highest nonvolcanic mountain) in Japan (3192 m) to the southern margin of the Suruga Trough, the elevation difference of $7000 \mathrm{~m}$ occurs within $160 \mathrm{~km}$ of lateral distance (in fact, the elevation difference probably exceeds $10,000 \mathrm{~m}$ if the top of the ocean crust is taken as a datum). This gradient is one of the largest land-connected slopes on the Earth and is comparable to the gradient of the Himalayas, which ranges from the foot of the lesser Himalayas to 8000 -m peaks in about 150 to $170 \mathrm{~km}$ lateral distance. Obviously this gradient provides the potential energy for the yield of coarse clastics into the deep-sea environments.

\section{Trench Sedimentary Facies}

Inspection of bathymetric maps and of longitudinal and transverse cross sections in available seismic profiles indicates some aspects of trench-fill processes. The longitudinal cross section of the Suruga and Nankai troughs shows that it is composed of a step-like topography (Fig. 23, also Kato et al., 1983). The first slope is developed at the mouth of the Fuji River, which makes up the most conspicuous slope. This slope apparently makes up the Fuji River fan-delta system. The many gullies developed on this slope are indicative of active gravity emplacement (Ohtsuka, 1980). 


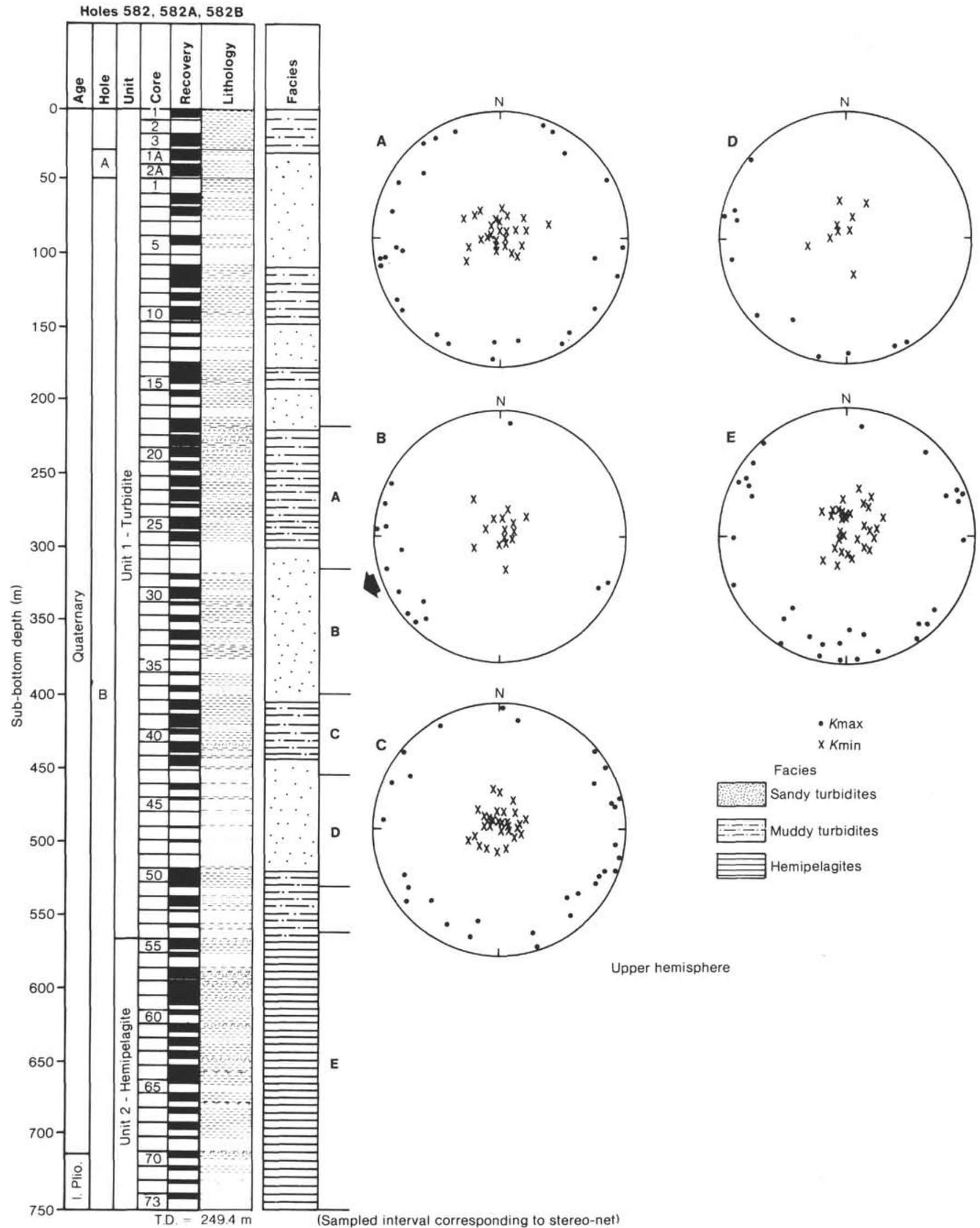

Figure 15. Magnetic susceptibility directions of Site 582 samples. A-E represent the stratigraphic interval for measured samples. Arrow indicates the interpreted paleocurrent direction. 


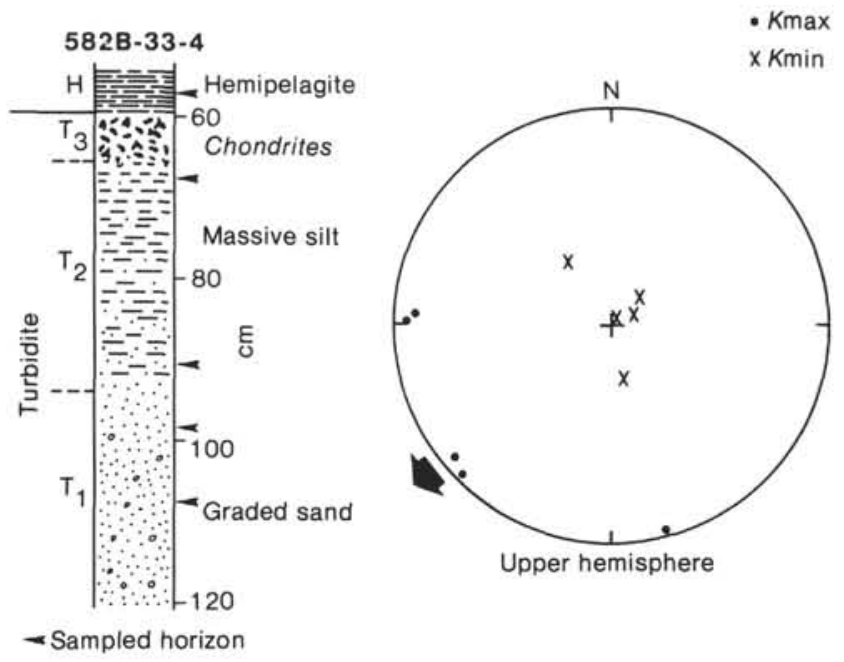

Figure 16. Magnetic susceptibility directions of a turbidite bed at Site 582. Arrow indicates the interpreted paleocurrent direction.

Two more steps (Profiles 3 and 5 in Fig. 23) are recognized toward the entrance of the Nankai Trough. Seismic profiles (Kato et al., 1982) reveal a difference in shape of the longitudinal channel from a sloped bottom to a flat bottom. In the sloped bottom of the trough, a narrow and relatively deep channel is recognized, whereas in the flat trough bottom, a wide and shallow channel is identified (Figs. 2 and 23).

Some of the available seismic profiles reveal an aspect of interaction between the development of trench sedimentary facies and tectonic deformation. The trench topography can be divided into four categories; outer slope, trench channel floor, inner swell, and toe of accretionary prism (Fig. 24). The last two topographic features coincide with the protothrust zone and the lower portion of the imbricated thrust zone of the Nankai Trough (Kagami et al., 1983).

A possible sedimentation pattern and facies model based on this trench topography classification emphasize two important aspects of trench sedimentary facies (Fig. 24). First, the trench turbidites are funneled through a longitudinal channel, thus forming a lenticular and troughlike sand body in transverse cross section. Second, as the trench-floor elevation gradually increases toward the toe of the accretionary prism, there is a wide zone of "overbank" deposition where diluted turbidity currents and occasional gigantic flows are accommodated. This facies pattern creates a fining-upward trench-fill depositional cycle similar to the one pointed out in the Middle American Trench (Moore et al., 1982). The facies starts from the trench central channel facies to levee facies, then to the finer-grained thin-bedded overbank turbidite and to slope hemipelagite. A similar fining-upward cycle is also recognized from the Cretaceous Shimanto subduction complex of Shikoku (Taira, in press).

\section{Tectonics and Trench Sedimentation}

The tectonism of central Japan has been controlled by two collisional systems; the Izu-Honshu collision (Niitsuma and Akiba, in press) and that of northeastern Japan against southwestern Japan at the Fossa Magna (Na-
$582 \mathrm{~B}-20-2,95-97 \mathrm{~cm}$

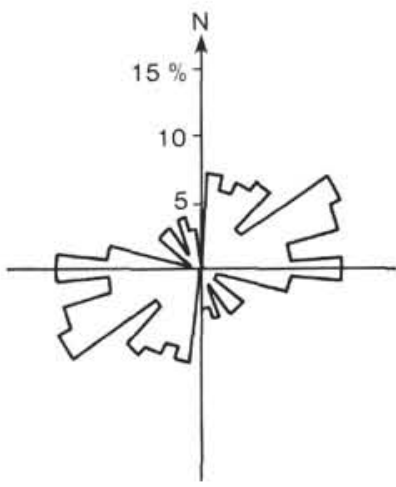

$582 \mathrm{~B}-30-3,43-45 \mathrm{~cm}$
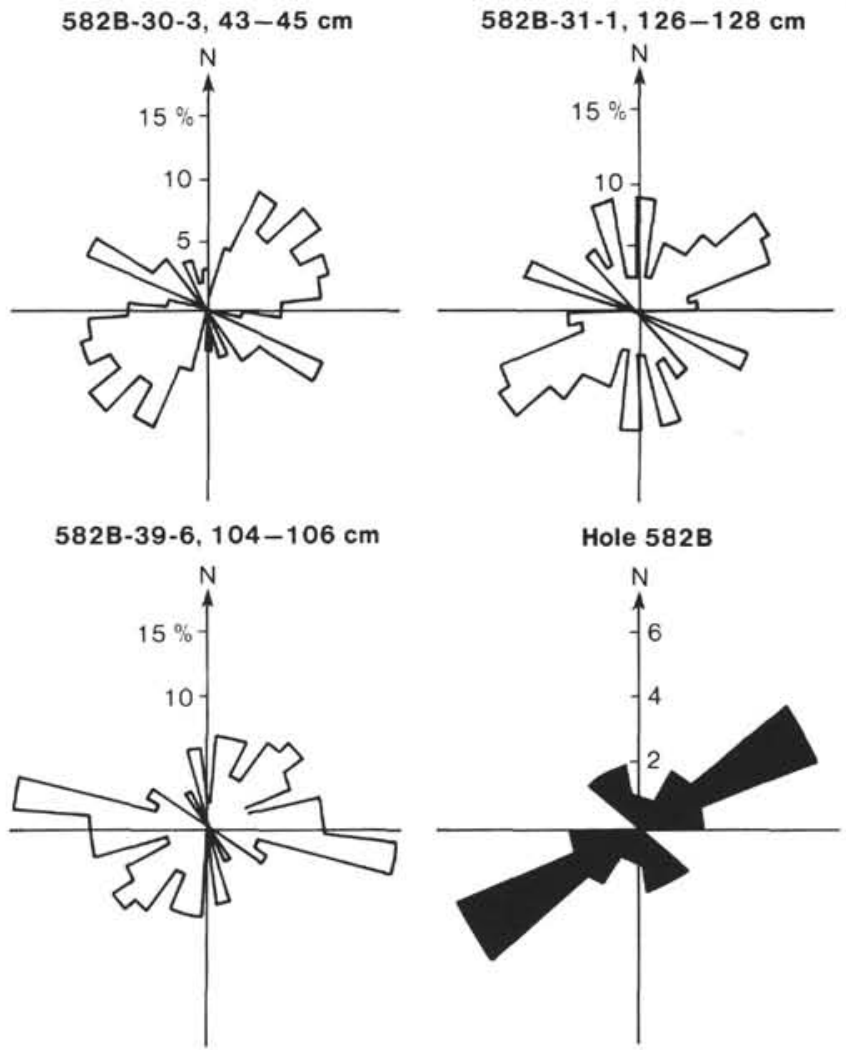

Figure 17. Grain orientation measured in thin sections, Site 582. Lower right shows a rose diagram for the mean directions of preferred orientation direction from 16 thin sections.

\section{$\stackrel{\stackrel{M}{3}}{\text { Current direction }}$}

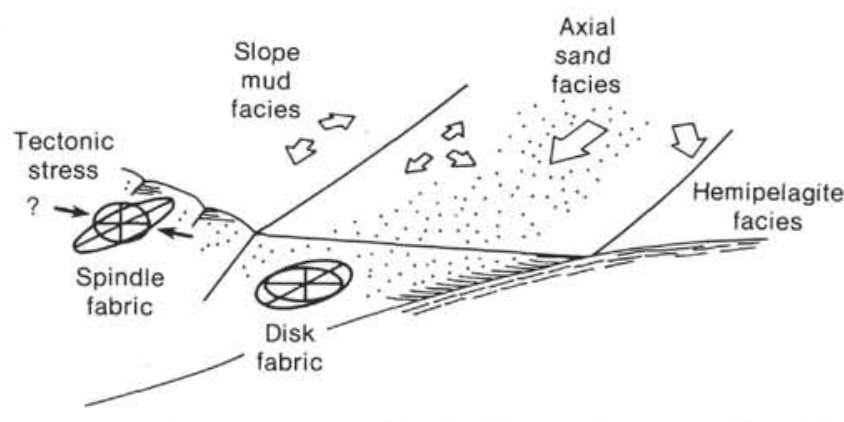

Figure 18. Illustration for paths of sediment dispersal and possible cause of sediment deformation. 


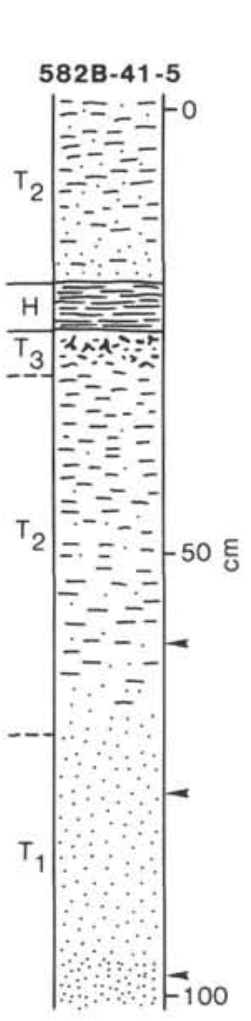

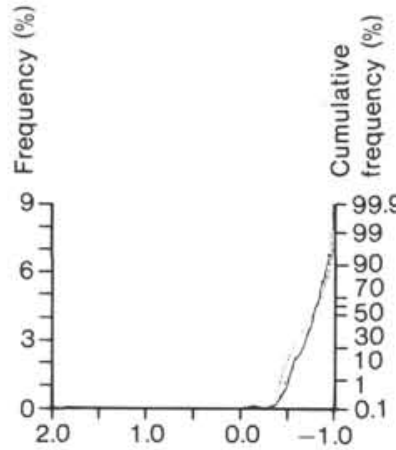
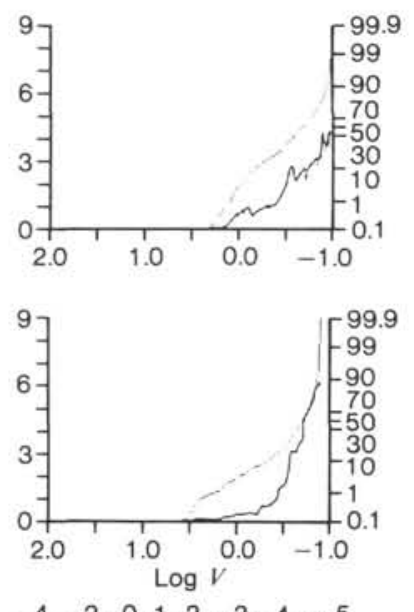

$-4--2 \cdots 0 \cdot-1 \cdots 2 \cdots-3 \cdots 4 \cdots \cdots 5$

Phi
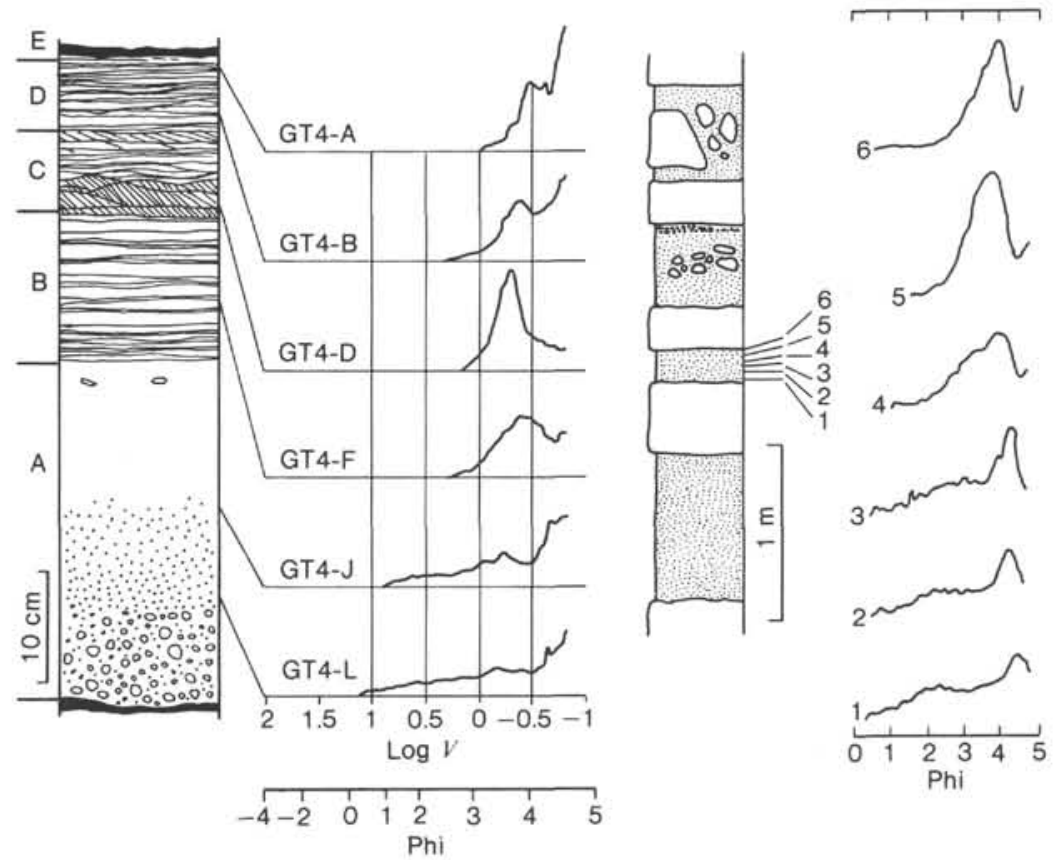

Figure 19. Grain-size (settling velocity) distributions for selected turbidite examples. A. Site 582. B. Pico Formation, Ventura Basin, California (after Taira and Scholle, 1979). C. Kokumoto Formation, Boso Peninsula, Japan (Niitsuma, 1974). See Figure 7 for explanation of frequency curves.

kamura, 1983). As the continuation of the Suruga Trough plate boundary seems to extend onto the coast of Shizuoka Prefecture, an event that created the sediment pathway to the Nankai Trough, we suggest that the IzuHonshu collision triggered the enormous yield of clastic sediment into the Nankai Trough. As a consequence of this collision, which began $\sim 2 \mathrm{Ma}$ (Niitsuma and Aki$\mathrm{ba}$, in press), the trench extends on shore between two land masses, and the deformation on land created the Japan Alps. A steep drainage system, formed along the strike-slip faults, provided coarse clastic sediment, creating a major fan-delta system at the river mouth. Occasional gigantic earthquakes destroyed the slope of the fan-delta and caused turbidity currents which flowed along the axis of the trough. Because this sediment yield was too rapid to be subducted, an accretionary prism formed at the base of inner trench slope.

\section{SUMMARY}

1. Turbidites encountered at Sites 582 and 583 have a characteristic sequence (Fig. 7).

2. Turbidites were emplaced from northeast to southwest as indicated by magnetic fabric analysis.

3. Settling tube analysis suggests that turbidity currents were composed of muddy, viscous flow with minor amounts of diluted secondary flow.
4. Petrographic analysis reveals that sands in DSDP samples were provided mainly from the Fuji River drainage system.

5. Physiographic considerations and grain-size data also support the above conclusion (Item 4) on provenance.

6. A trench turbidite-facies model involves a finingupward cycle (Fig. 24).

7. Rapid yield of trench turbidites was initiated by Izu-Honshu collision tectonics.

8. Rapid trench sedimentation was responsible for the creation of an accretionary prism.

\section{ACKNOWLEDGMENTS}

The authors thank Drs. Hideo Kagami and Dan Karig for their helpful discussions during the cruise. Reference samples used in this study were provided by the Geological Survey of Japan, Hydrographical Department of the Japanese Maritime Safety Agency, Ocean Research Institute of the University of Tokyo and Tokai University. A. T. thanks M. Imajo, M. Miyake, and Y. Okamura for their help in analysis of samples and preparation of the manuscript. N. N. thanks $\mathrm{Mr}$ M. Koyama for his help in measuring magnetic anisotropy. Drs. G. deV. Klein and J. Casey Moore reviewed the manuscript.

\section{REFERENCES}

Aoki, Y., Tamano, T., and Kato, S., 1982. Detailed structure of the Nankai Trough from migrated seismic sections. In Watkins, J. S., and Drake, C. L. (Eds.), Studies in Continental Margin Geology: Tulsa, Oklahoma (Am. Assoc. Pet. Geol. Mem.), 34:309-322. 
Graham, J. W., 1966. Significance of magnetic anisotropy in Appalachian sedimentary rocks. In Steinhard, J. S., and Smith, T. J. (Eds.), The Earth Beneath the Continents: Washington (Am. Geophys. Union), Geophys. Monograph, 10:627-648.

Harrold, P. J., and Moore, J. C., 1975. Composition of deep-sea sands from marginal basins of the Northwestern Pacific. In Karig, D. E., and Ingle, J. C., Jr., et al., Init. Repts. DSDP, 31: Washington (U.S. Govt. Printing Office), 507-514.

Kagami, H., Shiono, K., and Taira, A., 1983. Subduction of plate at the Nankai Trough and formation of accretionary prism. Kagaku, 51:429-438. (In Japanese)

Kaizuka, S., 1977. Topography of Japan: Tokyo (Iwanami-shoten). (In Japanese)

Kato, S., Sano, T., and Sakurai, M., 1983. Multi-channel seismic reflection survey in the Nankai, Suruga and Sagami Troughs. Rep. Hydrographic Res., 18:1-23. (In Japanese with English summary)

Koyama, M., and Niitsuma, N., 1983. Ring-core-type flux-gate spinner magnetometer and current-regulated three-axial alternating field demagnetizer. Geosci. Repts. Shizuoka Univ., 8:44-61. (In Japanese with English summary)

Mogi, A., 1977. Atlas of Submarine Topography around Japan: Tokyo (University of Tokyo Press). (In Japanese)

Moore, J. C., Watkins, J. S., McMillen, K. J., Bachman, S. B., Leggett, J. K., Lundberg, N., Shipley, T. H., Stephan, J.-F., Beghtel, F. W., Butt, A., Didyk, B. M., Niitsuma, N., Shephard, L. E., and Stradner, H., 1982. Facies belt of the Middle America Trench and forearc region, southern Mexico: results from Leg 66 DSDP. In Leggett, J. K. (Ed.), Trench-Forearc Geology: London (Geol. Soc. London), Spec. Publ., 10:77-94.

Nakamura, K., 1983. Possible nascent trench along the eastern Japan Sea as the convergent boundary between Eurasia and North American Plates. Bull. Earthquake Res. Inst. Univ. Tokyo, 58:711-722. (In Japanese with English summary)

Nakamura, K., and Shimazaki, K., 1981. Sagami-Suruga trough and plate subduction. Kagaku, 53:490-498. (in Japanese)

Nasu, N., et al., 1982. Multi-channel Seismic Reflection Data across Nankai Trough: Tokyo (Ocean Research Institute, University of Tokyo), IPOD-Japan Basic Data Series, No. 4.

Niitsuma, N., 1971. Automated grain size analyzer. Tohoku Univ. Inst. Geol. Paleontol. Contrib., 72:25-36. (In Japanese with English summary)

1974. Detailed study of sediments recording the Matsuyama-Brunhes geomagnetic reversal. Sci. Rep. Tohoku Univ. Ser. 2, 43:1-39.
Niitsuma, N., and Akiba, F., in press. Neogene tectonic evolution and plate subduction in the Japanese island arc. In Nasu, N., Kobayashi, K., Uyeda, S., Kushiro, I., and Kagami, H. (Eds.), Formation of Active Ocean Margins, 1983 Oji Seminar Proceedings: Tokyo (Terra Publ. Co.).

Ohtsuka, K., 1980. Results of piston-core sampling in Suruga Bay, central Japan during the research cruises KT-77-7 and KT-78-19 of R/V Tansei-Maru. Geosci. Rep. Shizuoka Univ., 5:23-30.

Okuda, Y., (Ed.), 1977. Geological Map off Outer Zone of Southwest Japan. Marine Geology Map Series, No. 8, Geol. Surv. Jpn., Tokyo.

Rees, A. I., 1965. The use of anisotropy of magnetic susceptibility in the estimation of sedimentary fabric. Sedimentology, 4:257-271.

Sato, T., 1962. Sand and gravel bed cored from the bottom of the Suruga Bay. J. Geol. Soc. Jpn., 68:609-617. (In Japanese)

Sugimura, A., 1972. Plate boundaries around Japan. Kagaku, 42: 170-181. (In Japanese)

1978. Iwanami-koza Chikyukagaku (Iwanami Earth Science Series), 10: Tokyo (Iwanami Shoten). (In Japanese)

Taira, A., in press. Sedimentary evolution of Shikoku subduction zone: Shimanto Belt and Nankai Trough. In Nasu, N., Kobayashi, K., Uyeda, S., Kushiro, 1., and Kagami, H. (Eds.), Formation of Active Margins, 1983 Oji Seminar Proceedings: Tokyo (Terra Publ. Co.).

Taira, A., and Lienert, B. R., 1979. The comparative reliability of magnetic, photometric and microscopic methods of determining the orientation of sedimentary grains. J. Sediment. Petrol., 49: 759-772.

Taira, A., and Scholle, P. A., 1977. Design and calibration of photoextinction settling tube for grain size analysis. J. Sediment. Petrol., 47:1347-1360.

1979. Deposition of resedimented sandstone beds in the $\mathrm{Pi}$ co Formation, Ventura Basin, California. Geol. Soc. Am. Bull., 90 952-962.

Taira, A., Saito, Y., and Hashimoto, M., 1983. The role of oblique subduction and strike-slip tectonics in the evolution of Japan. In Hilde, T. W. C., and Uyeda, S. (Eds.), Geodynamics of the Western Pacific-Indonesian Region: Washington (Am. Geophys. Union), Geodynamic Series 10:303-316.

Date of Initial Receipt: 3 April 1984

Date of Acceptance: 6 May 1985 

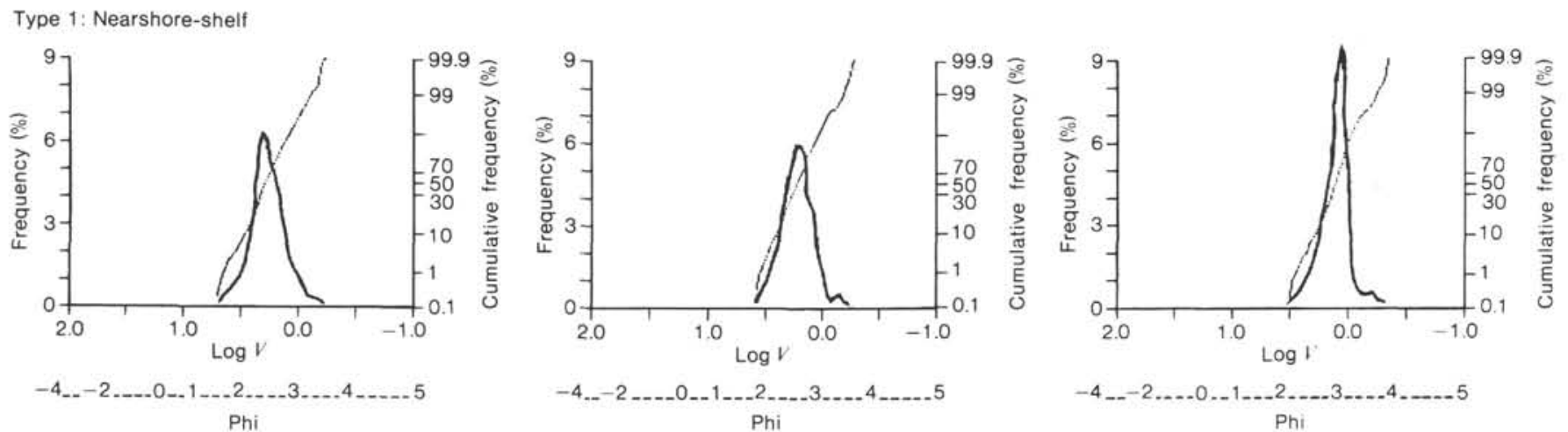

Type 2: Slope
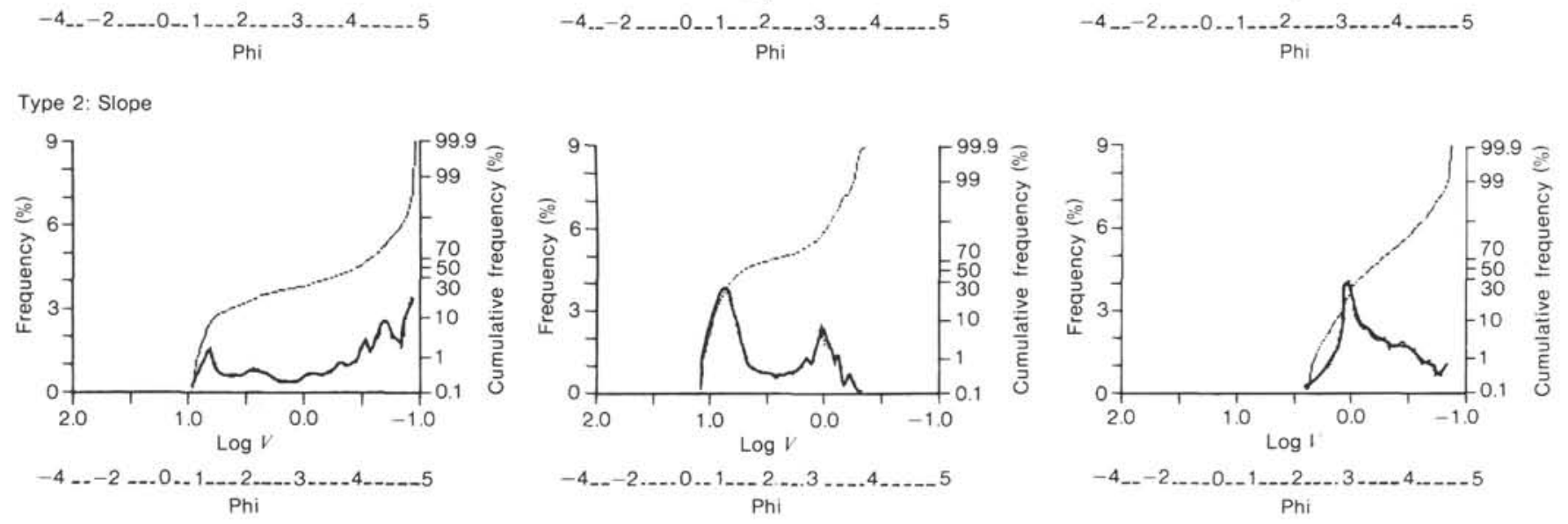

Type 3: Base of slope and trough
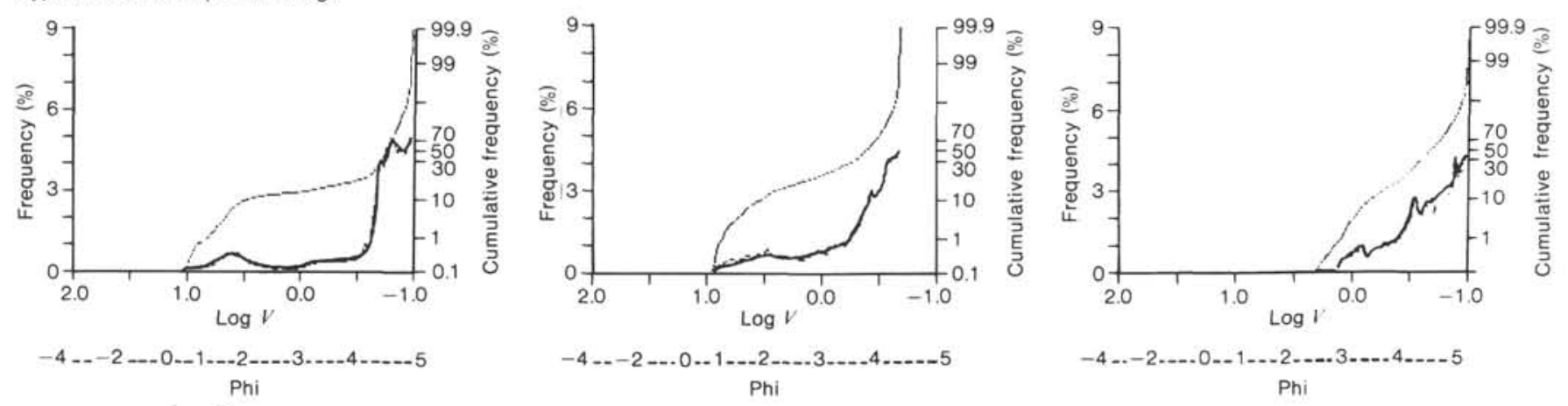

Figure 20. Selected examples of settling-velocity distributions for southwestern Japan offshore samples. 


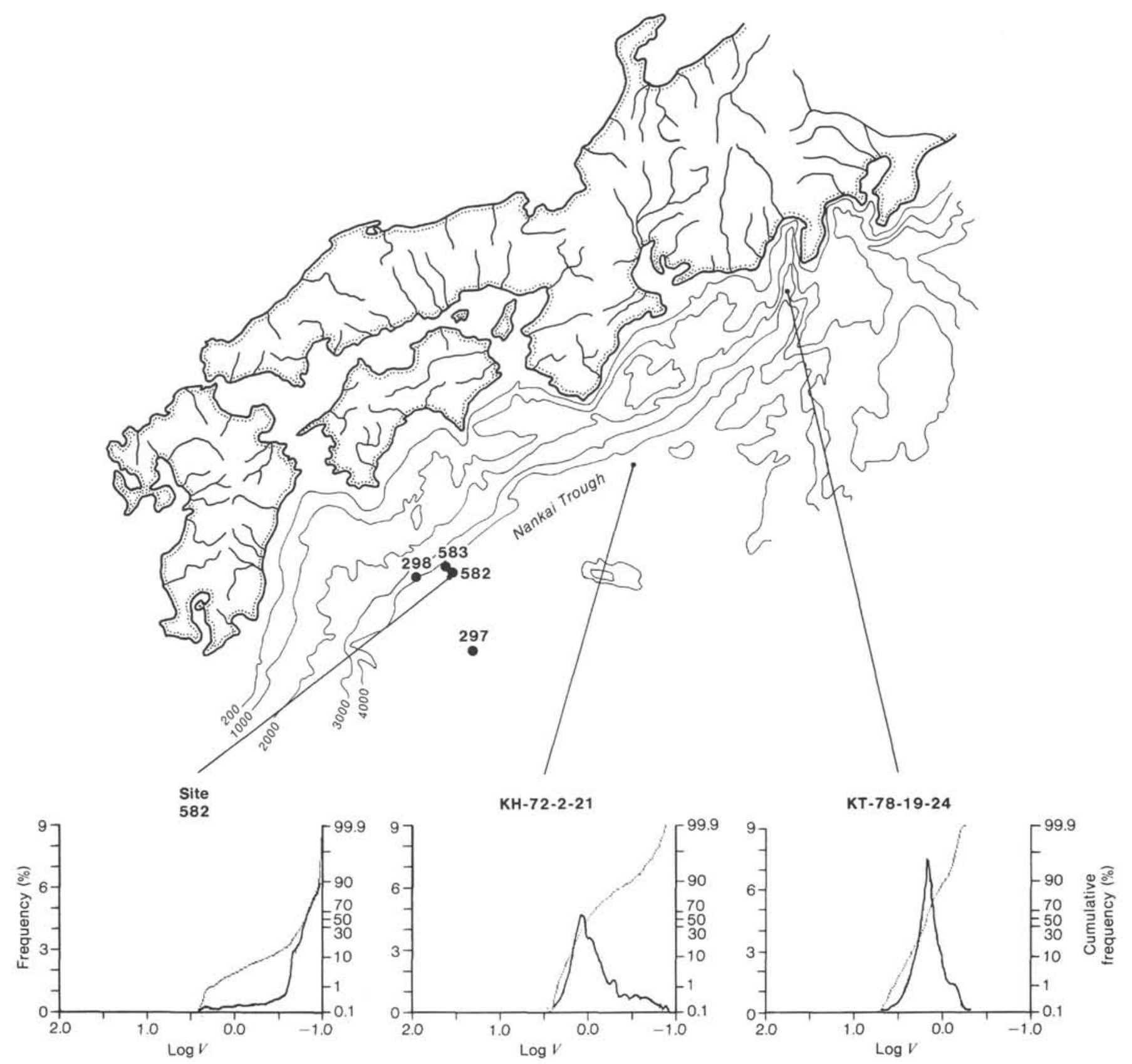

Figure 21. Settling-velocity distributions along the axis of the Suruga-Nankai Trough. 
Table 3. Tabulated point-count data (in \%) for sands of Site 582 and reference areas of southwestern Japan.

\begin{tabular}{|c|c|c|c|c|c|c|c|c|c|c|c|c|}
\hline Sample & Quartz & K-feldspar & Plagioclase & Sandstone & Shale & Chert & VRF & Glass & MRF & Mica & Pyroxene & Others \\
\hline 1. $582 \mathrm{~A}-1-1$ & 19.7 & 3.5 & 5.1 & 18.7 & 21.2 & 8.6 & 21.7 & 0.0 & 1.0 & 0.0 & 0.0 & 0.5 \\
\hline 2. $582 \mathrm{~A}-1-3,49-51$ & 17.7 & 2.3 & 10.0 & 9.2 & 20.8 & 5.4 & 16.9 & 1.5 & 2.3 & 3.8 & 5.4 & 4.6 \\
\hline 3. $582 \mathrm{~B}-2-1,49-51$ & 11.8 & 2.0 & 5.9 & 24.7 & 28.7 & 5.9 & 14.9 & 0.0 & 2.0 & 0.0 & 0.0 & 3.0 \\
\hline 4. $582 \mathrm{~B}-2-1,75-77$ & 16.5 & 1.8 & 11.9 & 6.4 & 18.3 & 7.3 & 30.3 & 0.0 & 1.8 & 1.8 & 2.8 & 0.9 \\
\hline 5. $582 \mathrm{~B}-5-1,52-54$ & 23.4 & 1.8 & 10.8 & 12.6 & 20.7 & 5.4 & 14.4 & 1.8 & 2.7 & 0.9 & 3.6 & 1.8 \\
\hline 6. $582 \mathrm{~B}-11-1,136-138$ & 23.9 & 3.7 & 10.1 & 13.8 & 18.3 & 2.8 & 11.9 & 1.8 & 0.9 & 5.5 & 3.7 & 3.7 \\
\hline 7. $582 \mathrm{~B}-15-1,59-61$ & 20.2 & 2.0 & 14.1 & 6.1 & 17.2 & 2.0 & 20.2 & 5.1 & 0.0 & 5.1 & 3.0 & 5.1 \\
\hline 8. $582 \mathrm{~B}-18-2,10-12$ & 16.9 & 0.0 & 8.5 & 8.5 & 14.1 & 4.2 & 39.4 & 2.8 & 1.4 & 0.0 & 4.2 & 0.0 \\
\hline 9. $582 \mathrm{~B}-18-2,10-12$ & 13.8 & 0.0 & 9.2 & 13.8 & 16.5 & 7.3 & 23.9 & 0.0 & 1.8 & 5.5 & 5.5 & 2.8 \\
\hline 10. $582 \mathrm{~B}-30-3,43-45$ & 19.1 & 2.2 & 11.2 & 14.6 & 26.9 & 5.6 & 13.5 & 1.1 & 2.2 & 1.1 & 2.2 & 0.0 \\
\hline 11. $582 \mathrm{~B}-30-3,43-45$ & 15.7 & 0.0 & 11.8 & 10.8 & 18.6 & 10.8 & 15.7 & 1.0 & 1.9 & 5.9 & 2.9 & 4.9 \\
\hline 12. $582 \mathrm{~B}-33-4,104-106$ & 36.5 & 1.0 & 5.8 & 14.4 & 19.2 & 5.8 & 4.8 & 1.0 & 1.9 & 5.8 & 1.0 & 2.9 \\
\hline 13. $582 \mathrm{~B}-39-4,104-106$ & 23.8 & 3.8 & 8.6 & 11.4 & 20.0 & 6.7 & 16.2 & 1.9 & 1.9 & 1.9 & 3.8 & 3.8 \\
\hline 14. $582 \mathrm{~B}-42-4,63-64$ & 31.2 & 0.0 & 10.4 & 7.8 & 29.9 & 3.9 & 6.5 & 2.6 & 0.0 & 5.2 & 0.0 & 2.6 \\
\hline 15. KH72-2-21, a-6 & 39.3 & 1.2 & 4.8 & 1.2 & 32.1 & 4.8 & 3.6 & 4.8 & 0.0 & 2.4 & 2.4 & 3.6 \\
\hline 16. $\mathrm{KH} 72-2-21$, a-7 & 26.4 & 0.7 & 5.7 & 10.7 & 17.9 & 15.0 & 8.6 & 4.3 & 2.1 & 3.6 & 1.4 & 3.6 \\
\hline 17. KH78-19-2 & 14.8 & 1.6 & 3.1 & 17.2 & 30.5 & 5.5 & 13.3 & 0.0 & 2.3 & 4.7 & 3.1 & 3.9 \\
\hline 18. KH78-19-21 & 22.9 & 1.3 & 3.8 & 3.8 & 55.7 & 1.3 & 5.1 & 1.3 & 2.5 & 1.3 & 1.3 & 0.0 \\
\hline 19. КH78-19-24 & 14.9 & 0.0 & 5.0 & 11.9 & 35.6 & 4.0 & 18.8 & 0.0 & 4.0 & 1.0 & 2.0 & 3.0 \\
\hline 20. Fuji River 1 & 23.9 & 2.2 & 4.3 & 2.2 & 30.4 & 1.1 & 17.4 & 0.0 & 0.0 & 7.6 & 4.3 & 6.5 \\
\hline 21. Fuji River 2 & 17.9 & 0.7 & 6.0 & 11.2 & 22.4 & 5.2 & 18.7 & 0.0 & 1.5 & 0.7 & 11.9 & 3.7 \\
\hline 22. BG 202 & 21.2 & 3.5 & 41.2 & 4.7 & 3.5 & 3.5 & 7.1 & 0.0 & 0.0 & 0.0 & 2.4 & 12.9 \\
\hline 23. BG 215 & 22.1 & 3.5 & 30.2 & 4.7 & 3.5 & 1.2 & 27.9 & 0.0 & 0.0 & 0.0 & 2.3 & 4.7 \\
\hline 24. BG 243 & 17.2 & 3.2 & 23.7 & 5.4 & 5.4 & 3.2 & 16.1 & 3.2 & 0.0 & 0.0 & 10.8 & 11.8 \\
\hline 25. BG 273 & 13.0 & 0.0 & 15.6 & 7.8 & 7.8 & 2.6 & 10.4 & 5.2 & 0.0 & 0.0 & 10.4 & 27.3 \\
\hline 26. HG 330 & 10.6 & 0.0 & 12.9 & 20.0 & 7.1 & 7.1 & 15.3 & 3.5 & 2.4 & 1.2 & 2.4 & 17.6 \\
\hline 27. HG 367 & 14.0 & 0.0 & 26.3 & 9.6 & 2.6 & 0.9 & 7.0 & 22.0 & 0.9 & 0.0 & 7.9 & 7.0 \\
\hline 28. HG 374 & 18.2 & 0.0 & 31.8 & 8.0 & 5.7 & 0.0 & 13.6 & 8.0 & 0.0 & 0.0 & 8.0 & 6.8 \\
\hline 29. Miyazaki Airport & 4.2 & 2.8 & 29.6 & 23.9 & 5.6 & 4.2 & 22.5 & 0.0 & 0.0 & 0.0 & 5.6 & 1.4 \\
\hline 30. Hitotsuba Beach & 9.9 & 2.0 & 18.8 & 13.9 & 5.0 & 4.0 & 24.8 & 0.0 & 0.0 & 0.0 & 18.8 & 3.0 \\
\hline 31. Hitotsuse River & 16.0 & 1.2 & 22.2 & 22.2 & 16.0 & 6.2 & 7.4 & 0.0 & 0.0 & 0.0 & 8.6 & 0.0 \\
\hline 32. TS 18 & 17.8 & 1.1 & 5.6 & 23.3 & 17.8 & 8.9 & 0.0 & 1.1 & 0.0 & 0.0 & 1.1 & 23.3 \\
\hline 33. TS 31 & 34.8 & 0.0 & 4.3 & 15.9 & 29.0 & 4.3 & 0.0 & 0.0 & 7.2 & 0.0 & 0.0 & 4.3 \\
\hline 34. TS 63 & 17.9 & 0.0 & 7.1 & 30.4 & 25.0 & 0.0 & 0.0 & 0.0 & 1.8 & 3.6 & 0.0 & 8.9 \\
\hline 35. MR 145 & 30.1 & 1.2 & 0.0 & 15.7 & 12.0 & 15.7 & 1.2 & 1.2 & 18.1 & 0.0 & 0.0 & 4.8 \\
\hline 36. JM 21 & 28.1 & 8.3 & 7.4 & 13.2 & 11.6 & 7.4 & 1.7 & 0.0 & 4.1 & 12.4 & 4.1 & 1.7 \\
\hline 37. JM 22 & 39.2 & 5.8 & 9.2 & 9.2 & 15.0 & 4.2 & 0.8 & 0.0 & 5.0 & 8.3 & 0.0 & 1.7 \\
\hline 38. JM 25 & 32.1 & 4.6 & 7.3 & 8.3 & 22.0 & 10.1 & 1.8 & 0.0 & 1.8 & 10.1 & 0.0 & 1.8 \\
\hline 39. JM 32 & 37.7 & 0.9 & 8.5 & 10.4 & 17.0 & 10.4 & 0.9 & 0.0 & 4.7 & 7.5 & 1.9 & 0.0 \\
\hline
\end{tabular}

Note: VRF = volcanic rock fragments; MRF = metamorphic rock fragments. DSDP samples (Samples 1-14) are expressed as hole-core-section, interval in $\mathrm{cm}$. Samples 1-14 are from Site 582, 15-16 from the Nankai Trough, 17-19 from the Suruga Trough, 22-31 from Kyushu, 32-35 from Shikoku, and 3639 from Tokai.

a Duplicate sample.

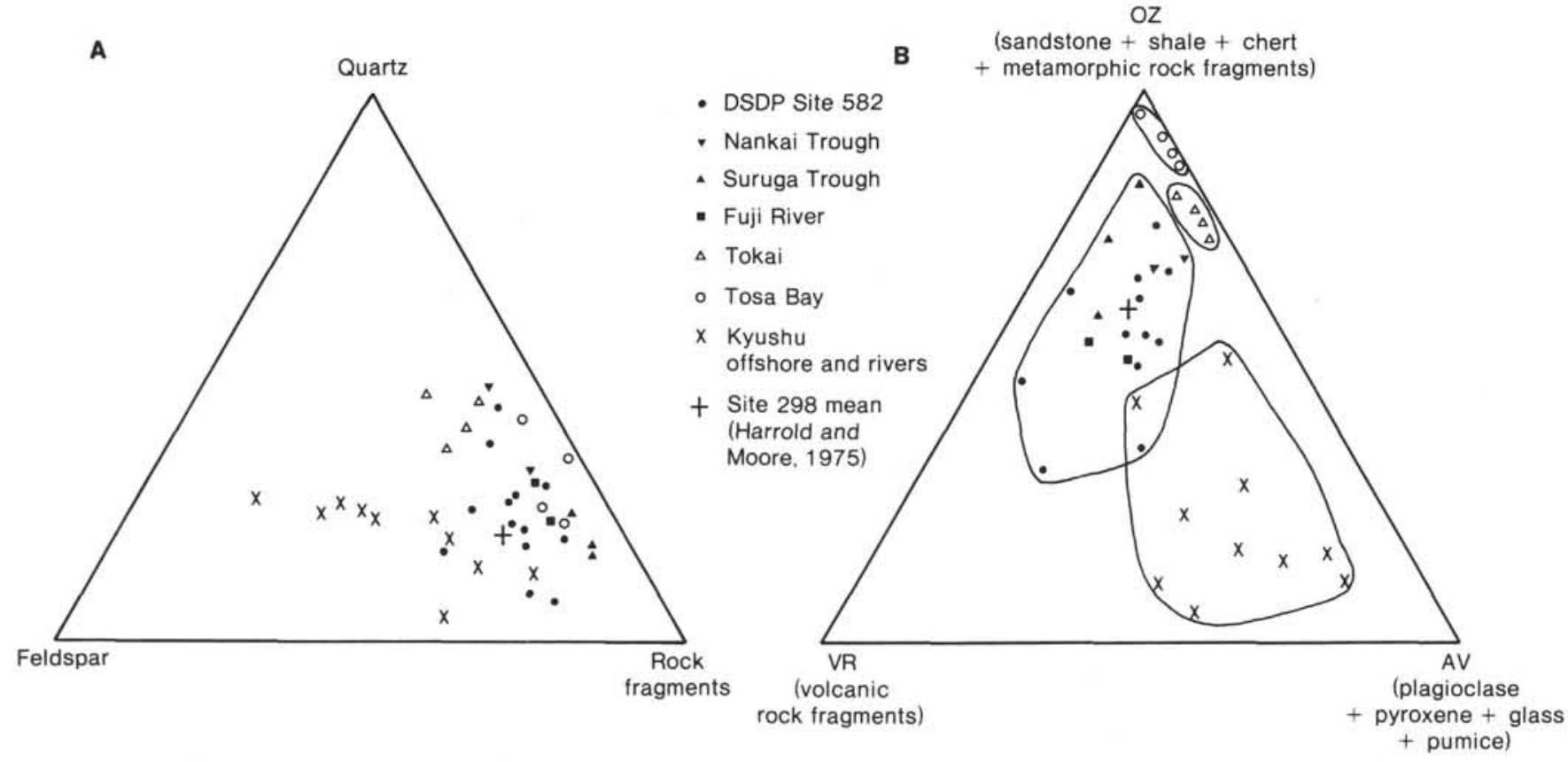

Figure 22. Ternary plots for compositions of sands of southwestern Japan offshore and river samples. 
A. TAIRA, N. NIITSUMA

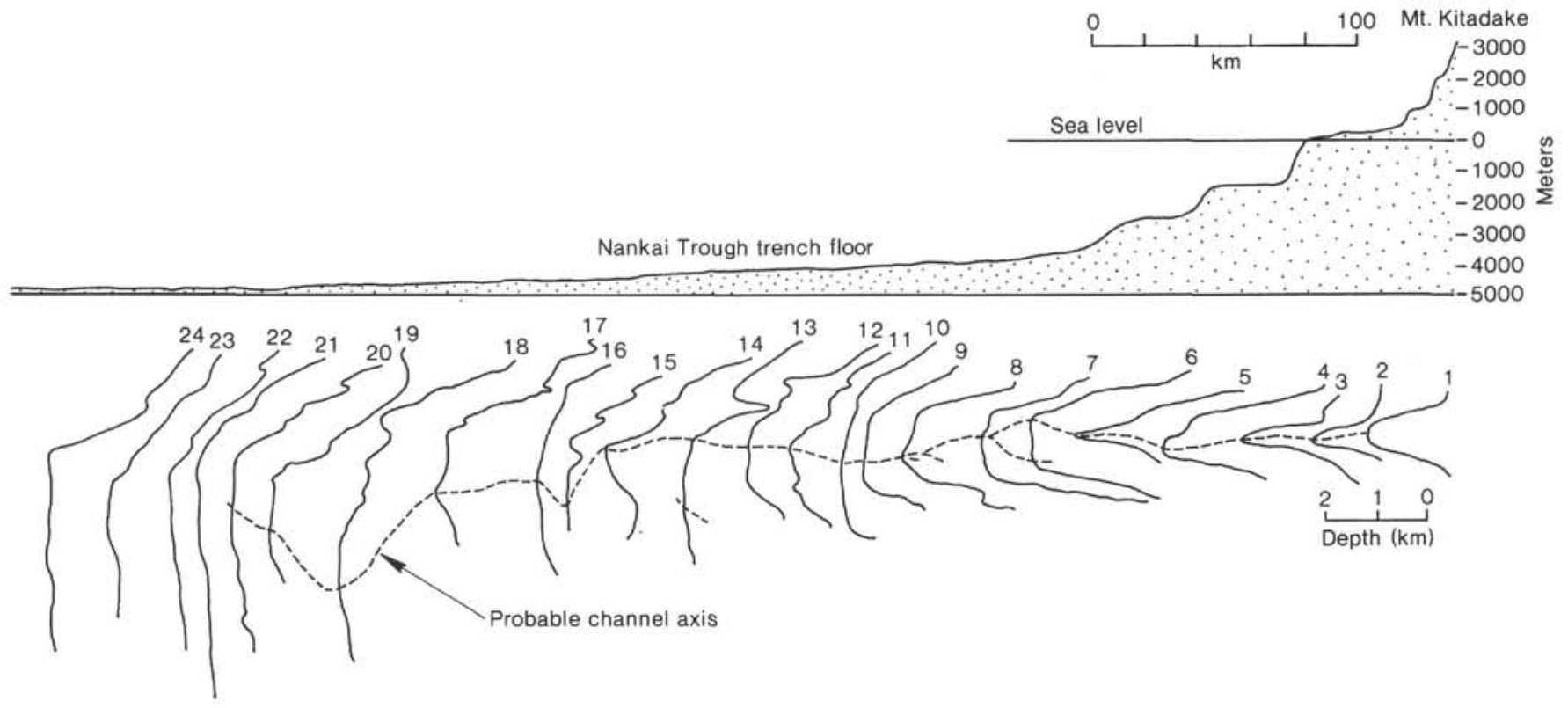

Figure 23. Longitudinal and transverse topographic cross sections for the Suruga-Nankai Trough. See Figure 3 for location of cross sections.

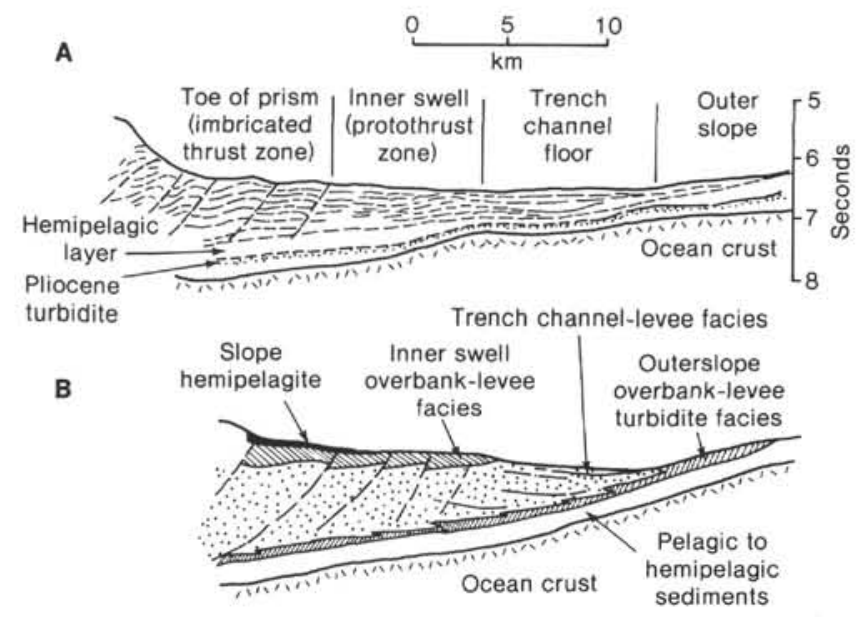

Figure 24. A. Representative seismic cross section at the Nankai Trough trench axis (after Aoki et al., 1982). B. Trench sedimentary facies model. 